\title{
Assessment of CMIP3-CMIP5 Climate Models Precipitation Projection and Implication of Flood Vulnerability of Bangkok
}

\author{
Seree Supharatid \\ Climate Change and Disaster Center, Rangsit University, Pathum Thani, Thailand \\ Email: supratid@yahoo.co.th
}

Received 26 January 2015; accepted 26 March 2015; published 27 March 2015

Copyright (C) 2015 by author and Scientific Research Publishing Inc.

This work is licensed under the Creative Commons Attribution International License (CC BY).

http://creativecommons.org/licenses/by/4.0/

(c) (i) Open Access

\begin{abstract}
Reliable estimates of precipitation are essential for both research and practical applications. CMIP3 and CMIP5 climate simulations provide both historical simulations and future projections of extreme climate. The 2011 monsoon season was one of case studies with exceptionally heavy and led to extensive and long-lasting flooding in the Chao Phraya river basin, Thailand. Flooding was exacerbated by the rapid expansion of urban areas into flood plains and was the costliest natural disaster in the country's history, with direct damages estimated at US\$45 billion. The present paper focuses on the precipitation downscaling of CMIP3 and CMIP5 models. The majority of CMIP3 and CMIP5 models overestimate the dry spell (in June and July) and underestimate the peak precipitation (in May and September). The interquartile model range for precipitation, which is spanned by the $25^{\text {th }}$ and $75^{\text {th }}$ quantiles, is closer to the observed data for CMIP5 than CMIP3 models. However, overall results suggest that the performance of CMIP5 models cannot be readily distinguished from of CMIP3 models, although there are clear signals of improvements over Bangkok. The correlation coefficient is found between $0.6-0.8$, implying that most of the models simulate the mean rainfall reasonably well. Both model generations have approximately the same standard deviation as observed, but more spatial variability and more RMS error are found for the future projections. Use of the Multi Model mean shows continuously increased rainfall from the near future to the far future while the Multi Model Median shows increased rainfall only for the far future. These findings in changing precipitation are discussed through the flood behavior in 2011. Results from flood simulation with several adaptation measures reveal that flood cannot be completely avoided. One of the best practices for highflood risk communities is to raise the house with open space in the first floor.
\end{abstract}

\section{Keywords}

Precipitation Downscaling, CMIP3, CMIP5, The 2011 Great Flood 


\section{Introduction}

The impact of global warming is likely to increase vulnerability to potentially damaging impacts of climate change, especially increase the frequency and harshness of weather events such as heavy rainfall, shifting in rainy season, increasing in number wet days. Several communities in the coastal area are vulnerable to a range of hazards, especially, coastal flooding. An increase in mean sea level and sea level extremes will mainly affect the terrestrial landscape, increasing the risk of inundation of low-lying coastal area. Coastal areas in both developing and more industrialized economies face a range of risks related to climate change and variability. Potential risks include accelerated sea level rise, increase in sea surface temperatures, intensification of tropical and extra tropical cyclones, extreme waves and storm surges, altered precipitation and runoff, and ocean acidification. The Intergovernmental Panel for Climate Change Fourth Assessment Report [1] points to a range of outcomes under different scenarios. It identifies a number of hotspots including heavily urbanized areas situated in the low-lying deltas of Asia and Africa as especially vulnerable to climate-related impacts. The number of major cities located near coastlines, rivers, and deltas provides an indication of the population and assets at risk. Thirteen of the world's 20 largest cities are located on the coast, and more than a third of the world's people live within 100 miles of a shoreline. Low-lying coastal areas represent 2 percent of the world's land area, but contain 13 percent of the urban population [2]. A recent study of 136 port cities showed that much of the increase in exposure of population and assets to coastal flooding is likely to be in cities in developing countries, especially in East and South Asia [3].

Several studies have emphasized that water resources are sensitive to climate change. Therefore, water resources management and planning strategies should be adjusted accordingly [4] [5]. One of the key climate variables is precipitation, which plays a dominant role in the hydrologic cycle. Developing future water resources management and planning strategies thus requires estimation of current and future precipitation magnitude and variability [6]. In the past several decades, global climate models have been used to estimate future projections of precipitation [7]. However, these projections are inherently uncertain and often are difficult for decision makers to interpret [8].

Since the Coupled Model Intercomparison Project (CMIP) was launched in 1995, coupled ocean-atmosphere general circulation models developed in dozens of research centers around the world have been compared and analyzed extensively. The program has improved our scientific understanding of the processes of Earth's climate system and of our simulation capabilities in this field. CMIP also plays an important social role by contributing to the Intergovernmental Panel on Climate Change (IPCC). The CMIP phase three (CMIP3) provided the scientific base for the Fourth Assessment Report (AR4) of IPCC published in 2007. Many climate projections in the past have relied on CMIP3 models [9]-[11]. Now, the SRES emission pathways are becoming older and a new set of emission scenarios called Representative Concentration Pathways (RCP) has been developed [12] [13]. Unlike the SRES scenarios that are detailed socioeconomic pathways, RCPs represent pathways of radiative forcing. Four RCPs are now available: RCP2.6, RCP4.5, RCP6.0 and RCP8.5. RCP nomenclature reflects socioeconomic pathways that reach a specific radiative forcing by the year 2100. For example RCP4.5 leads to a radiative forcing of $4.5 \mathrm{Wm}^{-2}$ by 2100 . RCP-based climate projections are now available from a number of climate models under the CMIP5 experiment (http://cmip-pcmdi.llnl.gov/cmip5/data_portal.html) [14].

The CMIP5 data are now available for analyses and are expected to provide new insights on our climate for the Fifth Assessment Report (AR5). The latest generation of Global Climate Models (GCMs), the framework of the fifth phase of the Coupled Model Intercomparison Project (CMIP5), reflects 5 - 6 years of effort by multiple climate modeling groups around the world. Compared to CMIP3, CMIP5 models typically have finer resolution processes, incorporation of additional physics, and better-developed or well-integrated earth system components [15]. Emerging literature on CMIP5 [16]-[18] has reported improvements in simulating certain key processes. Kug et al. [19] reported that CMIP5 suite of models performs slightly better than CMIP3 models in simulating two types of El-Nino events: Warm Pool El-Nino (a new type) and Cold Tongue El-Nino (the conventional El-Nino). A few studies have been performed on the intercomparison of the performance of CMIP3 and CMIP5 [20]. Blázquez and Nuñez [21] studied internal and inter-model variability in future climate projections with eight models of CMIP3 and CMIP5 over South America. Cattiaux et al. [22] studied historical biases and future uncertainties in temperature over Europe by CMIP5 and compared with the known results from CMIP3 models. However, other emerging studies have reported no improvements of note in CMIP5 compared to CMIP3 [23]. Mehrotra et al. [24] explored the potential skill of CMIP5 decadal hindcasts from 9 GCMs and their ensembles over the period 1960-2010 in Australia. Their results suggested that precipitation predictions show very limited skill when as- 
sessed at annual and multi-annual time-scales.

In addition, there is strong uncertainty in the projected changes in the magnitude and frequency of floods, while the GCM remains the largest source of uncertainties in hydrological projections at the river basin scale. Uncertainties from emissions scenarios and downscaling methods are also relevant, but likely smaller in magnitude [25] [26]. However, the relative uncertainty mix depends on the future time horizon, as uncertainties from emissions scenarios assume greater importance further into the future. Various downscaling and/or bias-correction techniques are applied to GCM/RCM outputs (e.g. precipitation and temperature) before hydrological simulations are conducted. This is one of a source of uncertainty. However, the relative importance of downscaling, bias-correction and the choice of hydrological models may depend on the selected region/catchment, the selected downscaling and bias-correction methods and the selected hydrological models [27]. Willems et al. [28] recommended an ensemble approach where several climate models, IPCC emission scenarios, and statistical downscaling techniques are considered. This allows the order of magnitude of the uncertainty levels caused by these approaches to be taken into account. Recently, Fiseha et al. [29] used the regional climate model (RCM) input to SWAT model with great success for the upper Tiber river basin in Italy.

This paper is organized as follows: We briefly explain the flood history and flood behavior of the 2011 Thailand great flood in Sections 2 and 3. We describe the multi-model ensembles and featured scenarios in Section 4 by analysing the differences in uncertainty range between the latest precipitation change projections provided by the fifth Coupled Model Intercomparison Project (CMIP5) generated for the upcoming fifth assessment report of the IPCC, and precipitation change projections used for the fourth IPCC assessment report (CMIP3). These projections for the climate from 2010 to 2099 are analysed at a monthly scale, and the results are used to force hydrodynamic models (Mike11 and Mike21) simulating the future response of flood inundation and adaptation measures at the basin scale in Section 5. We quantify the uncertainty in precipitation projections as a result of the range in the climate change projections, and show how this uncertainty differs between the CMIP3 and CMIP5 ensembles. The paper closes with concluding remarks in Section 6.

\section{Flooding History in Bangkok and Vicinity}

Bangkok covers an area of $1569 \mathrm{~km}^{2}$ located in the delta of the Chao Phraya river basin which is the largest basin in the country, covering an area of $159,000 \mathrm{~km}^{2}$ or about $35 \%$ of the total land area of the country. There are two main rivers bisecting the delta area: the Tha Chin river on the west and the Chao Phraya river (the main stream) on the east. The basin forms up by 4 large tributaries: the Ping, Wang, Yom, and Nan originate from the mountainous terrain in the northern part of the country. These four tributaries flow southward to join each other in Nakhon Sawan to become the Chao Phraya river. The river flows southward through a large alluvial plain to reach the sea at the Gulf of Thailand as illustrated in Figure 1. The basin area is flat at an average elevation of 1 to $2 \mathrm{~m}$ from the mean sea level (m.MSL), with certain spots where the elevation is lowered down to the sea level due to land subsidence. There are a number of canals crossing the whole basin. Bangkok straddles the Chao Phraya river $33 \mathrm{~km}$ north of the Gulf of Thailand. Due to the flatness of the area and close proximity to the seashore, the area annually faces the problems of floods from rivers from the north and inundation due to the high tide from the sea.

As the capital and largest city, it has about 7 million people and 12 million people in Bangkok Metropolis, and contributions to $43 \%$ GDP. Bangkok's location on floodplains where natural waterways and wetlands have been drained, filled, and replaced with urban structures makes the city vulnerable to flooding. Over the past three decades, severe flooding in Thailand has become increasingly common. Figure 2 shows the flood extents of five of the most severe floods in the Thailand's recent history. Not shown in this figure are the floods of 2010 and 2011. The 2011 floods in the Chao Phraya basin were the worst floods ever recorded in the country, and the estimated US\$45.7 billion in costs make it more expensive than Hurricane Katrina [30]. After the 1983 floods, and again after the 1995 and 2006 floods, the Thai government began massive projects to prevent future floods in the Chao Phraya basin. The so-called "Master Plan” for flood mitigation after 1983 led to the creation of a polder system of levees and pumps surrounding Bangkok [31]. The 1995 Master Plan improved the polder system in and around Bangkok by expanding and strengthening the levees and pumps along the Chao Phraya, and by building retention ponds and several drainage tunnels in the area. After 2006, the Master Plan extended the polder system of pumps and levees to the eastern suburbs of Bangkok. However, Bangkok is still under threat of flooding, especially the increasing flood risk due to climate change and the rapid urbanization in the floodplain. 


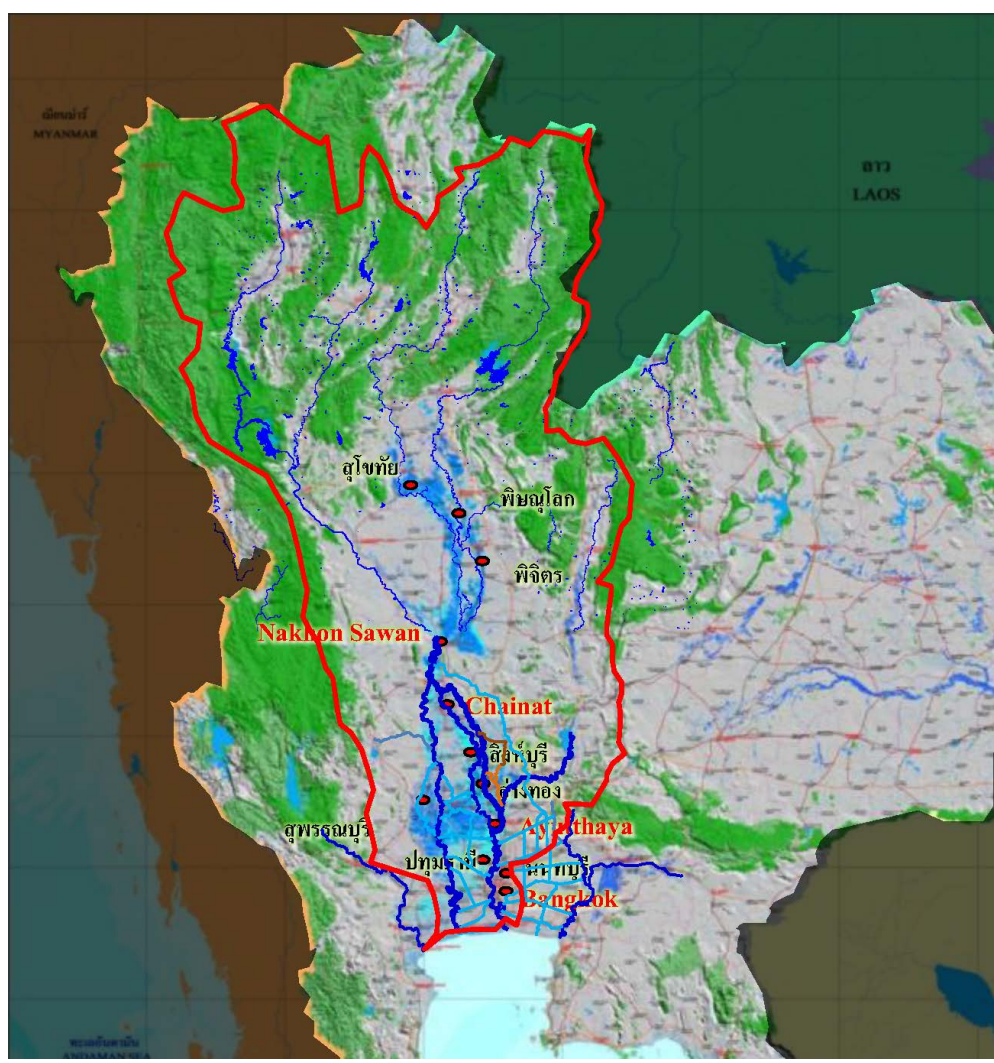

Figure 1. Chao Phraya river basin.

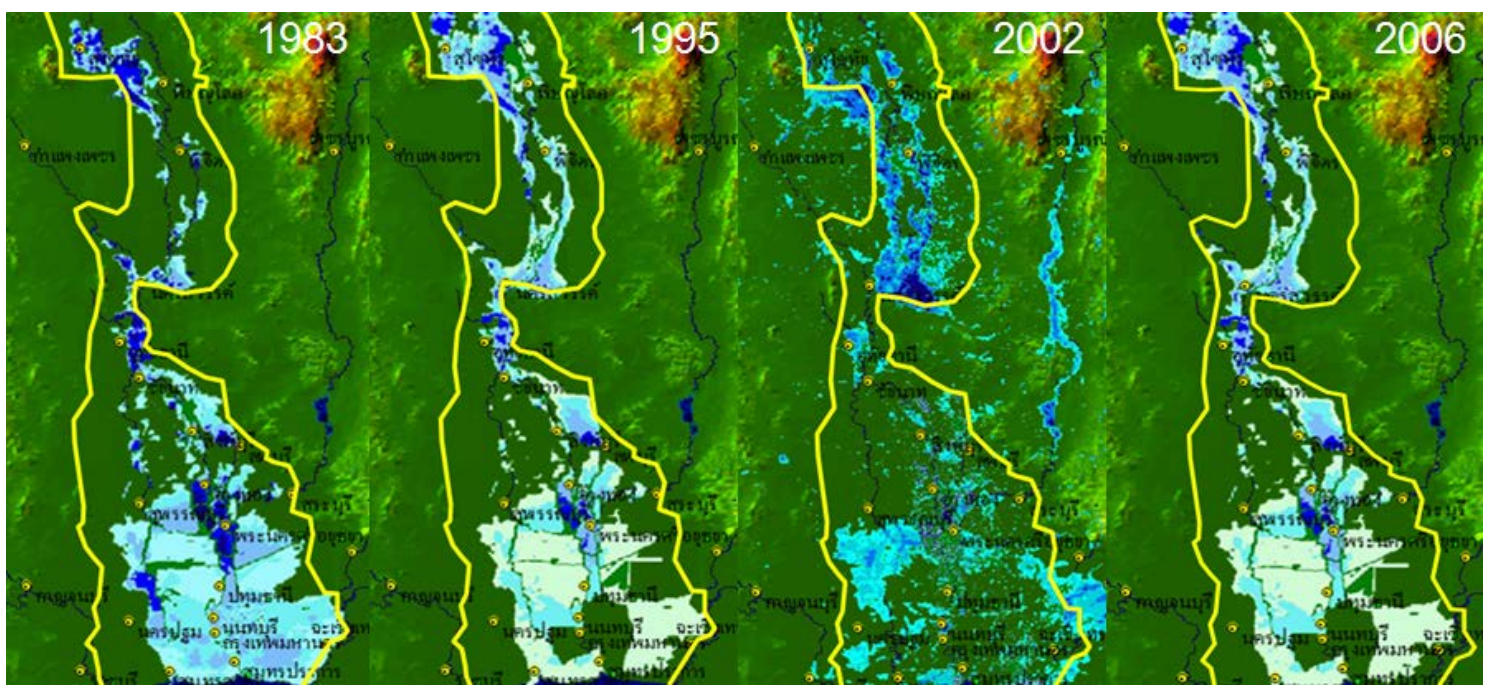

Figure 2. Past severe floods in the Chao Phraya river basin.

The frequency of devastating floods tends to be higher and the loss of human lives and property show increasing sign.

\section{Looking Back on the 2011 Thailand Great Flood}

Flood devastation such as in Thailand in 2011 is not simply the result of extreme rainfall and poor reservoir management. It results from failure to prepare for recurrent floods [32]. In this section, flood behavior is described. 


\subsection{Flood Behavior}

Although efforts have been made to mitigate the flood damage in the Chao Phraya river basin through several structural measures (construction of dams, reservoirs, dikes and pumping stations), flooding still causes much more impact as a result of deforestation, farmland expansion and urban development. The flood damage potential is increasing due to rapid urbanisation and land development in downstream areas; particularly in Ayutthaya and its municipalities along the Chao Phraya river.

The 2011 rainy season was influenced by both the northwest monsoon and the tropical storm, commencing with Nock-Ten which made landfall at Vietnam and became a tropical depression before moving to Thailand at the end of July (Nan province). In addition, there were four storms (Haima, Haitan, Nesat and Nalgae) that caused medium to heavy rainfall from June to October in the north and northeast of Thailand (see Figure 3). The continuous rainfall in the north accumulated nearly $1675 \mathrm{~mm}$ of water, which is $42 \%$ more than the 30 -year average value (see Figure 4). This causes significant accumulated run-off volume passing Nakon Sawan province more than 30,000 mcm compared to approximately 25,000 and 27,000 mcm in 1995 and 2006 floods, respectively as given in Figure 5. Due to the limited capacity of the Chao Phraya river and the Pasak river, several riverbank overflows occurred, and dykes along the river were broken causing excessive flow to many communities beside the river and downstream. The inundation area was estimated to be $14,000 \mathrm{~km}^{2}$ with the flood volume of approximately $10,000 \mathrm{mcm}$ in the floodplain from Nakon Sawan to Ayuthaya (see Figure 6). In total, the floods damaged 18,291 km² of farmland and 804 factories, and killed 813 people.

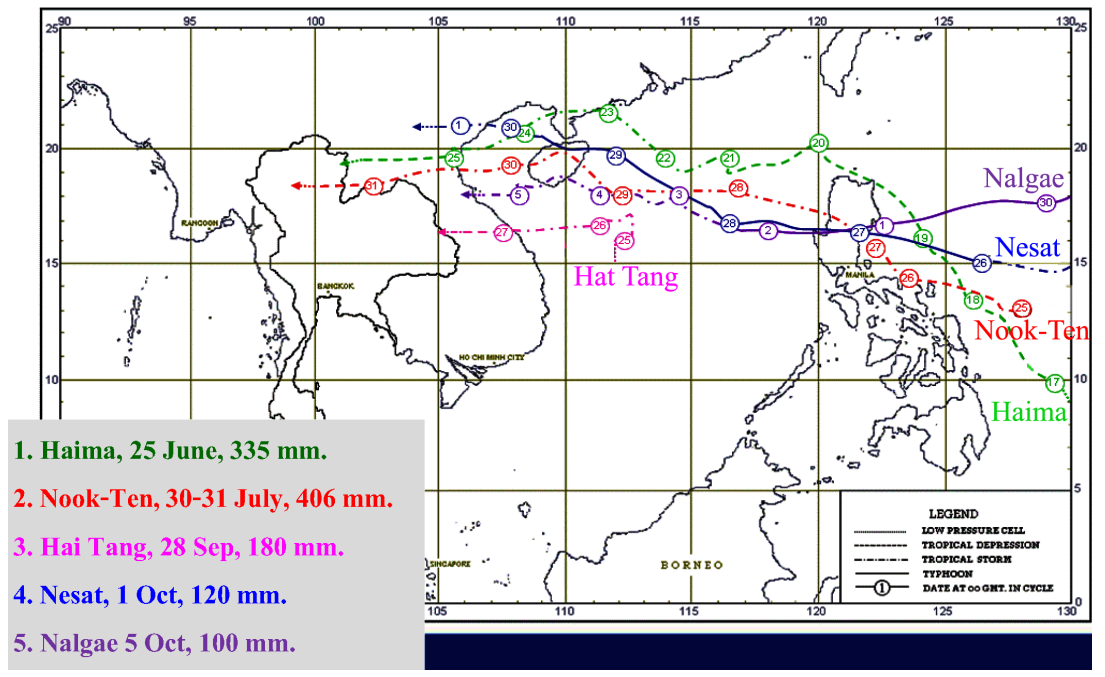

Figure 3. Storm tracks in 2011 (TMD).

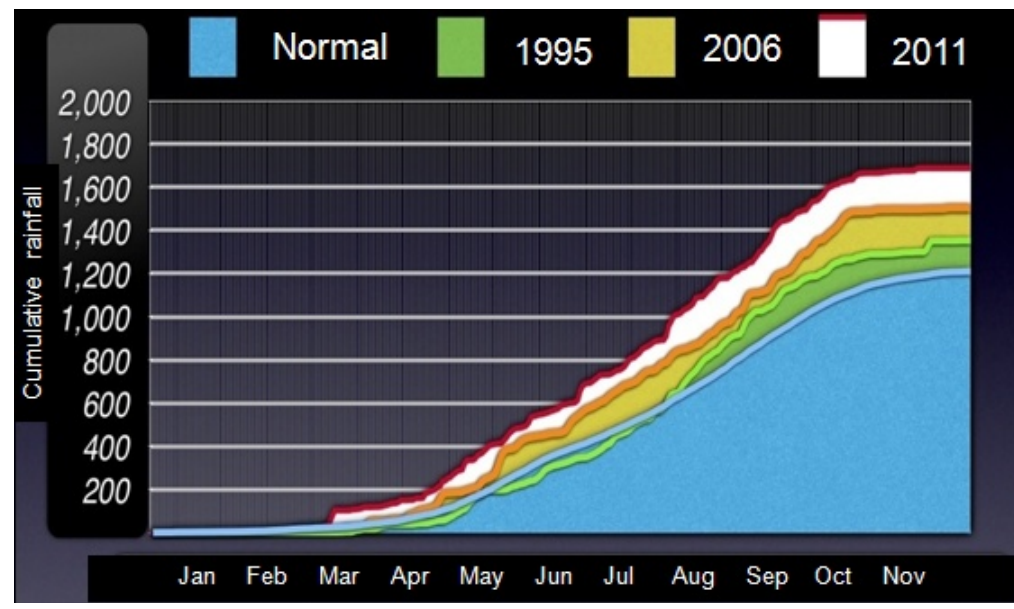

Figure 4. Cumulative rainfall in the northern part. 


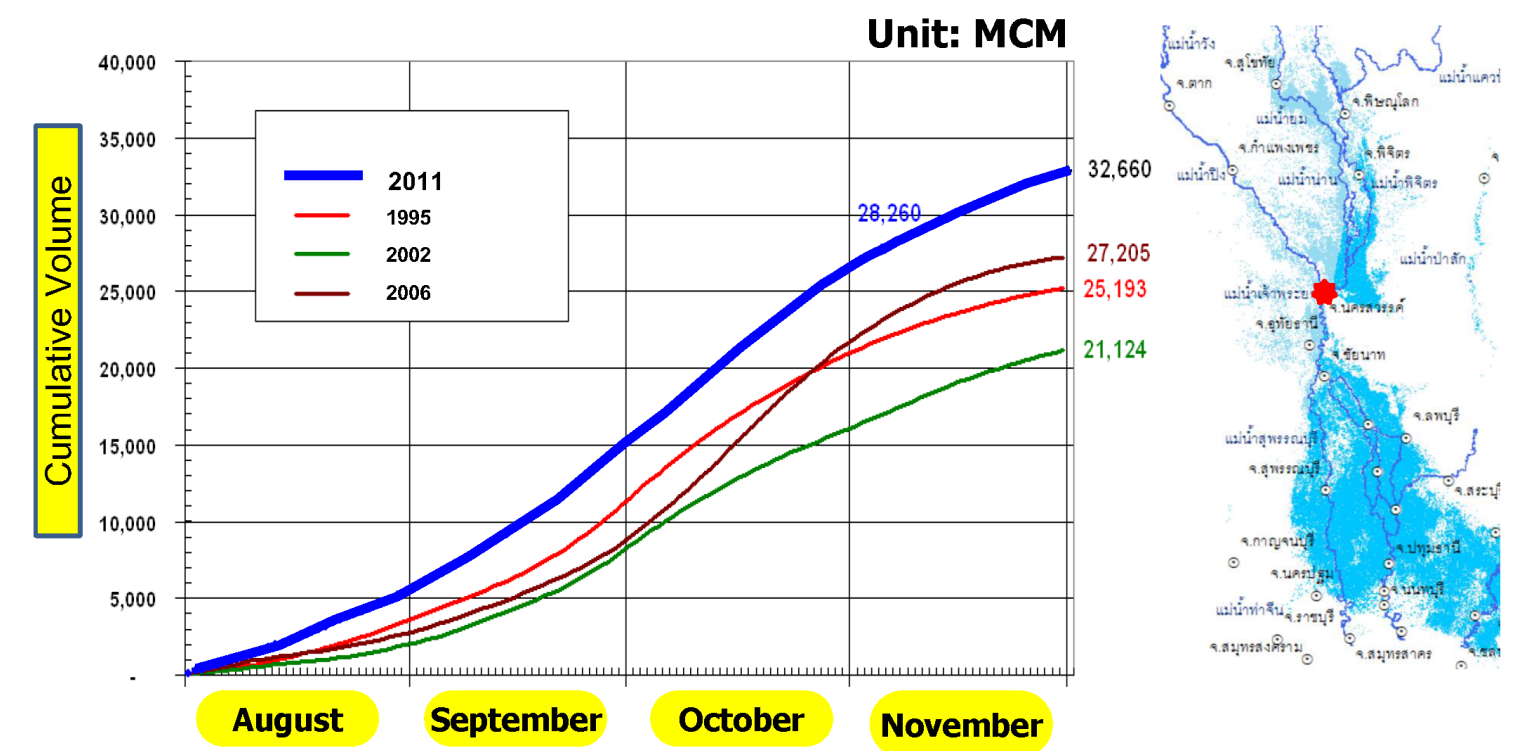

Figure 5. Run-off volume passing Nakorn Sawan.

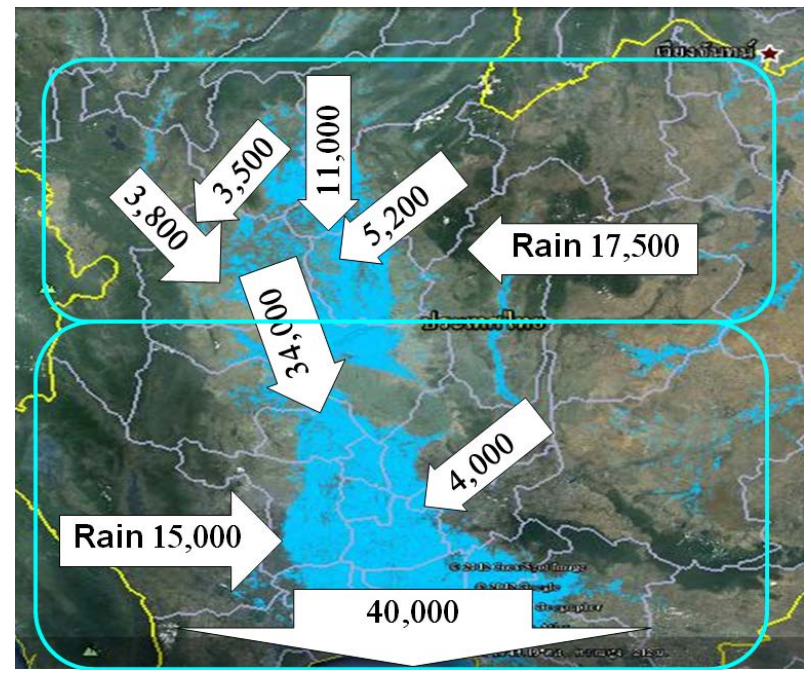

Figure 6. Flood inundation area and flood volume (RID).

\subsection{Timeline of the 2011 Flood}

During the time of the flood, the general public could easily access the information regarding the rainfall and the flood as follows:

MAR: Precipitation began at the end of March (2 months earlier than a normal year).

APR: Low rainfall rate continued similar to a normal year.

MAY: Monthly rainfall was recorded at a very high level relative to the past 30 years. Water storage in the two largest upstream reservoirs (Bhumibol and Sirikit) was at a level far below the lower dam operation rule curve.

JUN: Typhoon "Haima" caused heavy rain in late June and water storage in both reservoirs start significant rising, especially the Sirikit dam.

JUL: At the end of July, there was intense rainfall due to the effects of Typhoon "Nock-Ten". Monthly rainfall was the highest in the past 30 years. Flooding occurred at the confluence of the Yom river lower basin and the Nan river downstream from the Sirikit Dam. Water storage in both reservoirs showed continuously rising.

AUG: There was a lot of rain in August in both the northern and central parts, and water storage in the Sirikit reservoir began to exceed the higher dam operation rule curve. In addition, flooding had begun in the area near 
Nakon Sawan, and it was no longer possible to increase preliminary release to prevent flooding downstream from both reservoirs.

SEP: The highest monthly rainfall in the past 30 years. The Sirikit reservoir almost became full. Discharge of the Chao Phraya river exceeded its discharge capacity from Nakon Sawan to Ayutthaya, and began to overflow. In the middle of the month, water gates on the right bank were destroyed by the flood, and thus massive flooding occurred. At the end of the month, levees on the left bank broke one after another, and there was flooding of around 5 billion $\mathrm{m}^{3}$, which was estimated from the difference in the hydrograph between the upstream and downstream parts at the levee breakage location. Some major dike breaching locations are shown in Figure 7.

OCT: Rainfall was in line with an average year. The Bhumibol reservoir almost became full. The flooding of the left bank in late September moved to the south, inundating a series of industrial estates on the left bank.

By early October the two reservoirs stored approximately 10 billion $\mathrm{m}^{3}$, which is an amount equivalent to two-thirds of the total flood volume. Figure 8 shows the inflow and release from the 2 major upstream reservoirs (Bhumibol and Sirikit dams). Several inflow peaks occurred after the passage of 5 storms mentioned before. The overbank flow occurred during the middle of September at several downstream communities from Nakorn Sawan. The water level in both reservoirs rose sharply and touched the maximum pool level during the first week of October. The sudden released discharge of Bhumibol dam (more than $100 \mathrm{mcm} /$ day) and the Sirikit dam (more than $50 \mathrm{mcm} /$ day) caused tremendous impact on the downstream communities, especially the industrial estates. Therefore, flood forecasting and dissemination for better flood preparedness is a critical issue [33]. Tarolli [34] gave valuable comments on how to inform vulnerable community with better communication system. One of the most advance system is the operational system based on Delft-FEWS [35], which has been operational since 2005 for all eight EA (Environmental Agency) regions in UK [36].

\subsection{Inundated Industrial Estates}

Within the first 3 weeks of October, seven major industrial estates were submerged 2 - $3 \mathrm{~m}$ during high flood level (see Figure 9). This caused interruption to supply chain to car parts regionally and world-wide, e.g. electronic components and hard disk drives. The Ministry of Industry estimated damage in various industrial estates (i.e. Saharatna Nakorn, Rojana, Hi-tech, Bang Pa-in, Factoryland, Nawanakorn and Bang Kadi) to be approximately THB 237.4 billion, and in affected provinces to be THB 237.3 billion. Combined with the results from the survey, which includes Bangkok, the total damage is estimated to be THB 513.9 billion. Similar to the estimated damages, the Ministry of Industry estimates the losses from reduced production in the aforementioned

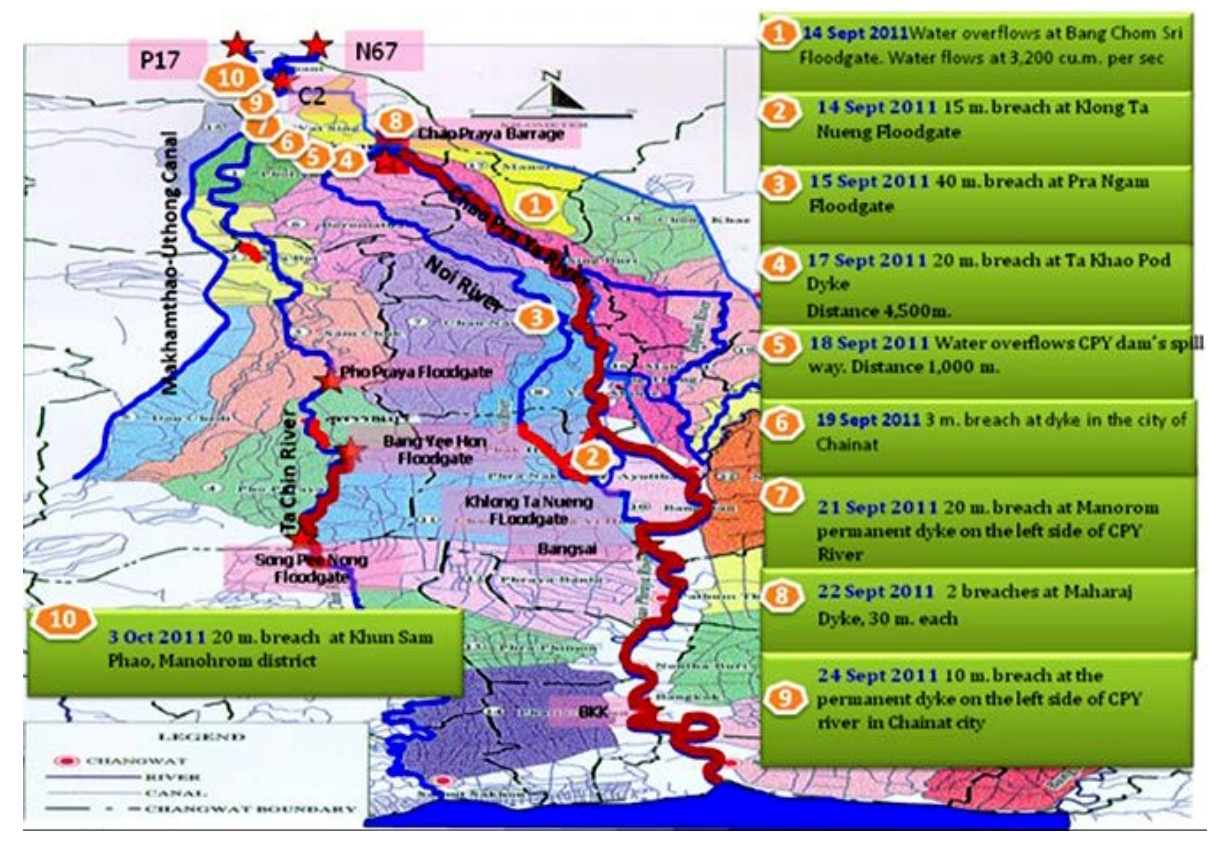

Figure 7. Timeline of dike breaching locations (RID). 


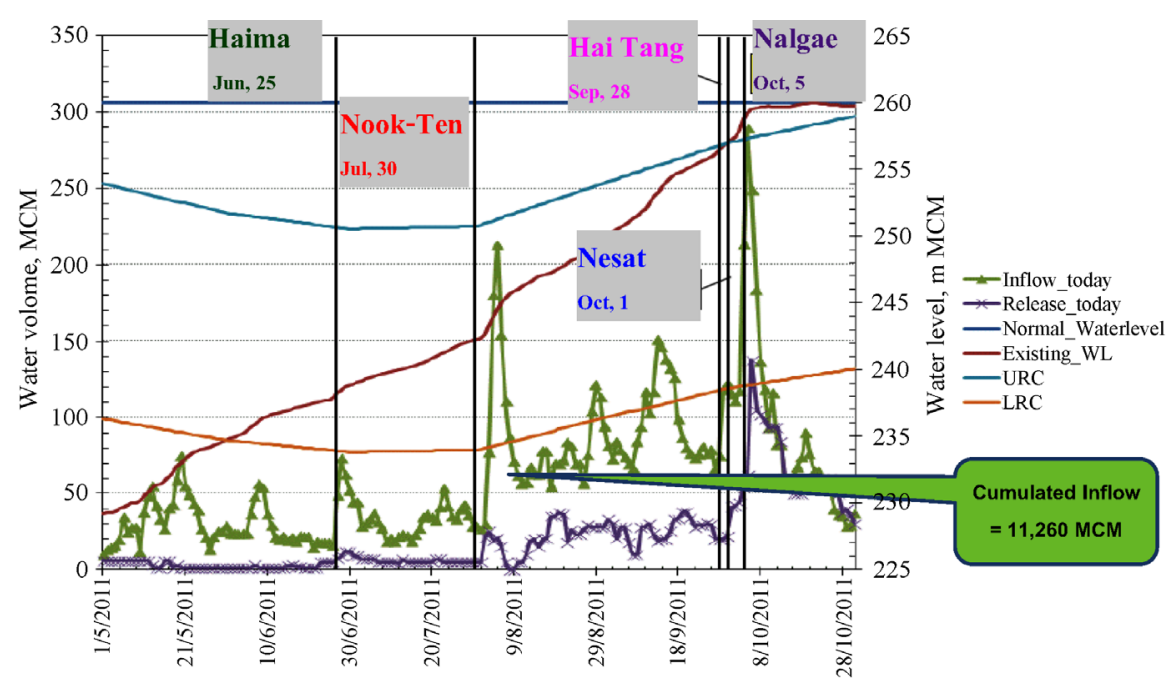

(a)

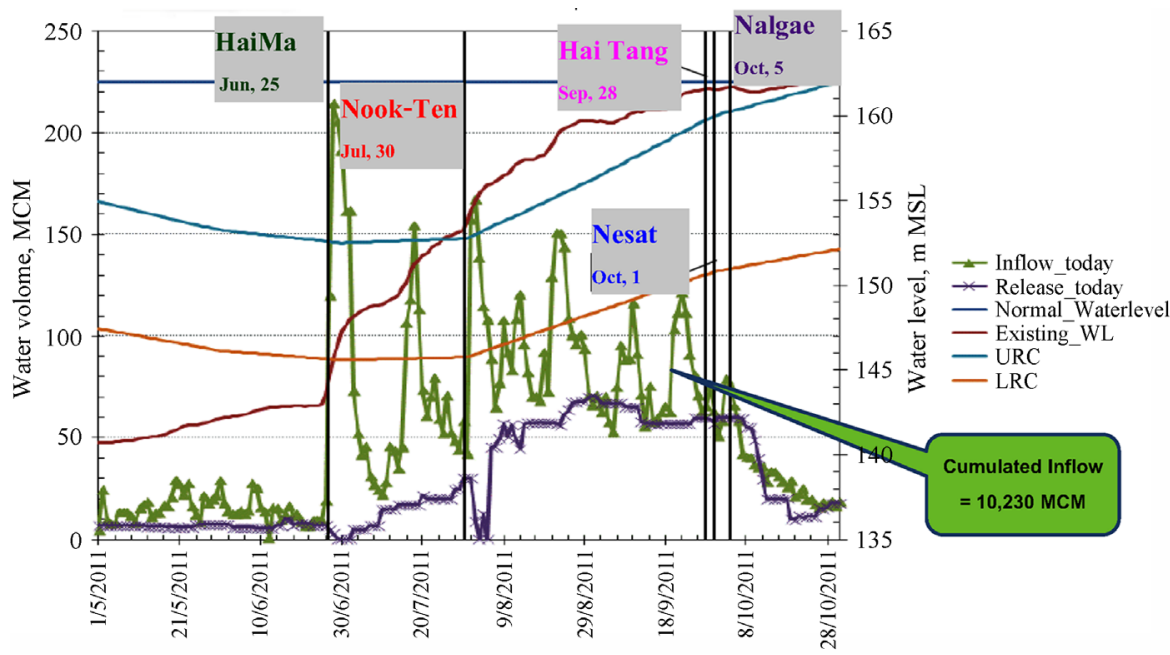

(b)

Figure 8. Inflow and release of the Bhumibol and Sirikit dams (RID). (a) Bhumibol dam; (b) Sirikit dam.

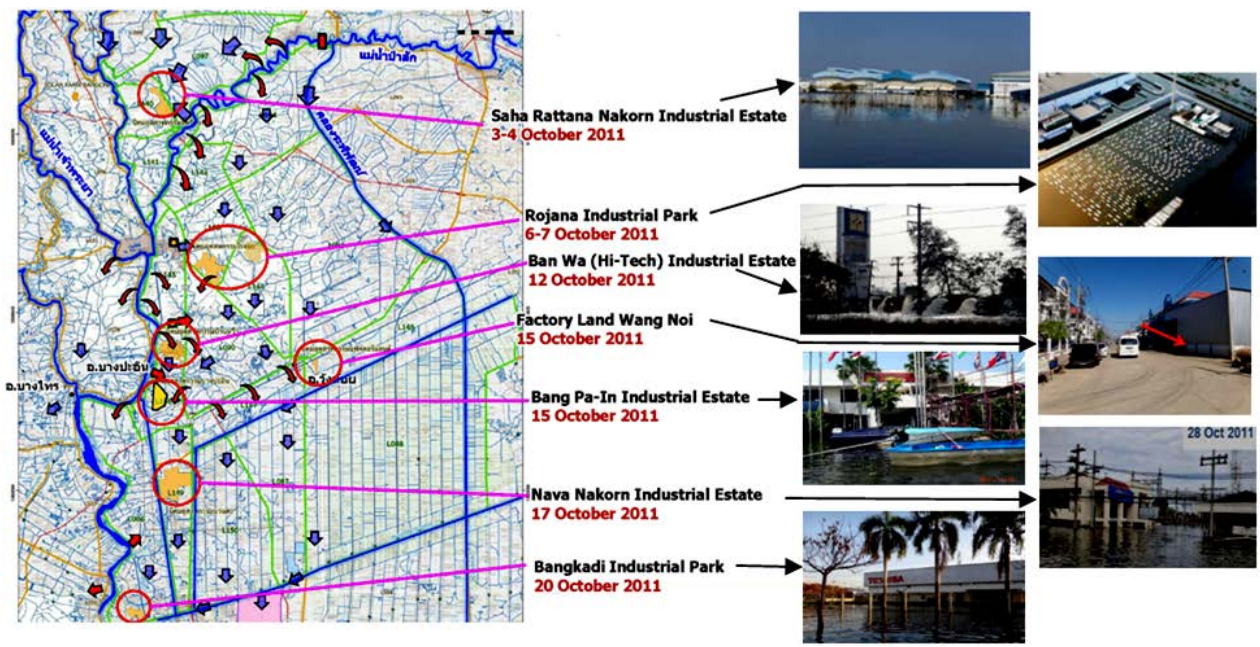

Figure 9. Flood inundated 7 industrial estates. 
industrial estates in Ayuthaya and Pathum Thani to be around THB 328 billion. Combined with the surveyed data in the other of the five provinces and extrapolated for 26 affected provinces according to the industry sector GPP data, the losses are estimated at THB 493 billion [37].

\section{Climate Models and Scenarios}

In the present study, we investigate the capability of CMIP3 and CMIP5 models in simulating precipitation over land through historical twentieth century skills and future projections. A performance ranging from time series plots and Taylor diagrams are used for intercomparisons. Therefore, we use 9 climate model pairs from CMIP3 and CMIP5 downscaling for Bangkok (see Table 1). The horizontal resolution of the CMIP5 models is generally improved for the majority of the models.

Monthly precipitation data have been extracted from 9 climate model pairs from CMIP3 and CMIP5. We have examined mean climatology for historical period (1980-1999), for the near future period (2010-2039), for the mid future period (2040-2059) and the far future period (2080-2099) with only one initial condition ensembles, "run1" from CMIP3 and "r1i1p1" from CMIP5. In this study, we considered last two decades of the twentieth century and extracted from "20c3m" and "historical" experiments from CMIP3 and CMIP5, respectively. Future monthly precipitation data has been taken from comparable greenhouse warming scenarios, SRES B1 and A2 from CMIP3 and RCP4.5 and RCP8.5 from CMIP5 models. The IPCC AR4 scenarios SRES (B1, A1FI) have been reported to best match the (RCP4.5, RCP8.5) temperature and total anthropogenic RF projections [38] [39] as given in Figure 10. All these models were regrided to a 0.5 degree (720 longitude $\times 278$ latitude) as shown in Figure 11. Daily precipitation data for the period 1980-1999 were obtained from Thailand Meteorological Department (TMD) for Bangkok station, it is located in the central of Bangkok, with latitude 13.73N and longitude 100.56E.

The multi model mean times series plots were generated by calculating the mean value of time series data from 9 model pairs. Time series data from an individual model were generated by taking the average of annual mean precipitation from 1980 to 1999 and 2006 to 2099. Figure 12 show time series plots of the mean annual precipitation for MME. Also shown in this figure is the historical time series plot for annual mean from observation (OBS) data sets: Bangkok station (TMD). A comparison of the time series plot of mean annual rainfall from any of the reference data set shows that CMIP5 models do not show improvement over CMIP3 model in term magnitude. The annual cycle of the mean precipitation for 9 pairs of CMIP3-CMIP5 models is shown in Figure 13. It is found that most CMIP5 models give precipitation peak in September (agree with the observed data) while CMIP3 models give precipitation peak in August. Two models of CMIP3 (MRI-CGCM2.3.2, INM-CM3.0) and five models of CMIP5 (Miroc-CGCM3, GISS-E2-H, CSIRO-Mk3.6, GFDL-ESM2M, GFDL-CM3) give double peaks of mean precipitation similar to the observed data. The lower peak in May indicates the southwest monsoon season beginning while the higher peak in September indicates influence of southwest monsoon and the ITCZ (Inter Tropical Convergence Zone). The lower precipitation (Dry spell) in June and July is caused by a rapidly northwards moving of the ITCZ across southern China. The majority of CMIP3 and CMIP5 models overestimate the dry spell and underestimate the peak precipitation.

Table 1. List of CMIP3 and CMIP5 global climate models used in this study

\begin{tabular}{ccccc}
\hline CMIP3 & Resolution & CMIP5 & Resolution & Center \\
CNRM-CM3 & $128 \times 64$ & CNRM-CM5 & $256 \times 128$ & Centre National de Recherches Meteorologiques, France \\
CSIRO-Mk3.0 & $192 \times 96$ & CSIRO-Mk3.6 & $192 \times 96$ & CSIRO, Australia \\
GFDL-CM2.0 & $144 \times 90$ & GFDL-CM3 & $144 \times 90$ & Geophysical Fluid Dynamics Laboratory, NOAA \\
GFDL-CM2.1 & $144 \times 90$ & GFDL-ESM2M & $144 \times 90$ & Geophysical Fluid Dynamics Laboratory, NOAA \\
GISS-ER & $72 \times 46$ & GISS-E2-H & $144 \times 90$ & Goddard Institute for Space Studies, USA \\
INM-CM3.0 & $72 \times 45$ & INM-CM4 & $180 \times 120$ & Institute of Numerical Mathematics, Russia \\
IPSL-CM4 & $96 \times 72$ & IPSL-CM5A-LR & $96 \times 96$ & Institute Pierre Simon Laplace, France \\
MIROC3.2 (medres) & $128 \times 64$ & MIROC5 & $256 \times 128$ & CCSR/NIES/FRCGC, Japan \\
MRI-CGCM2.3.2 & $192 \times 96$ & MRI-CGCM3 & $320 \times 160$ & Meteorological Research Institute, Japan
\end{tabular}




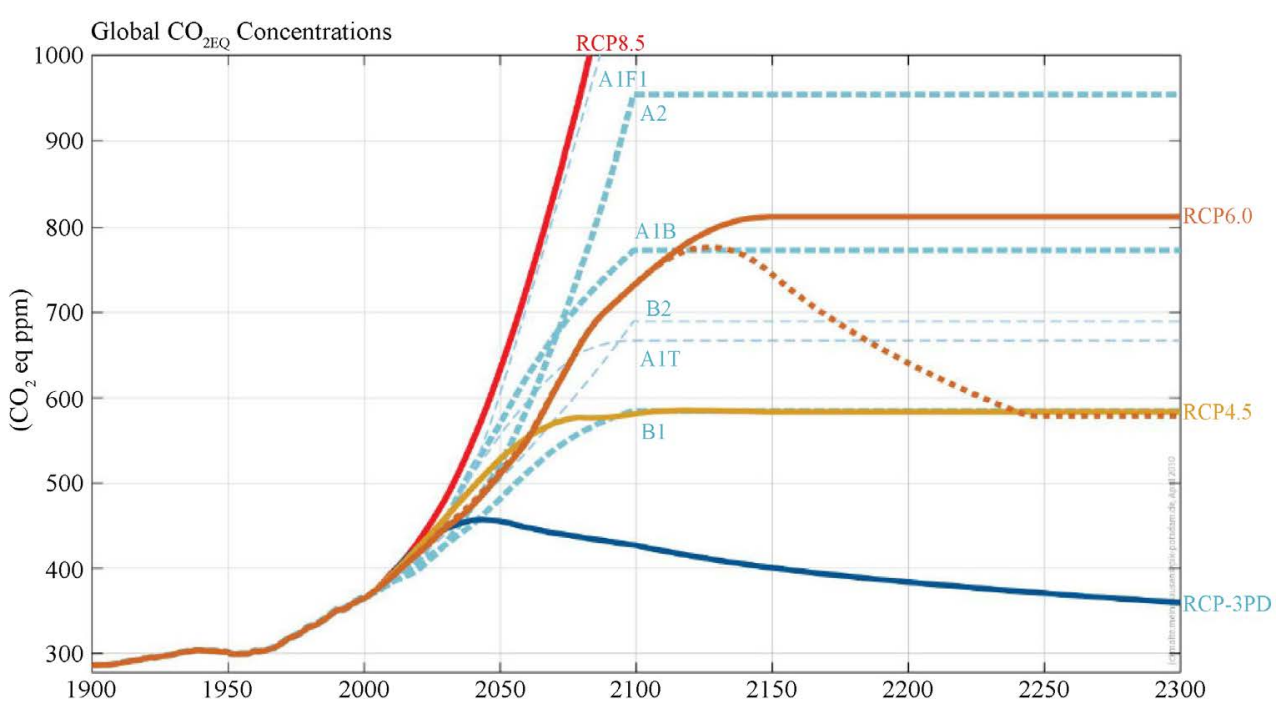

Figure 10. Relationship between SRES and RCPs (adapted from [43]).

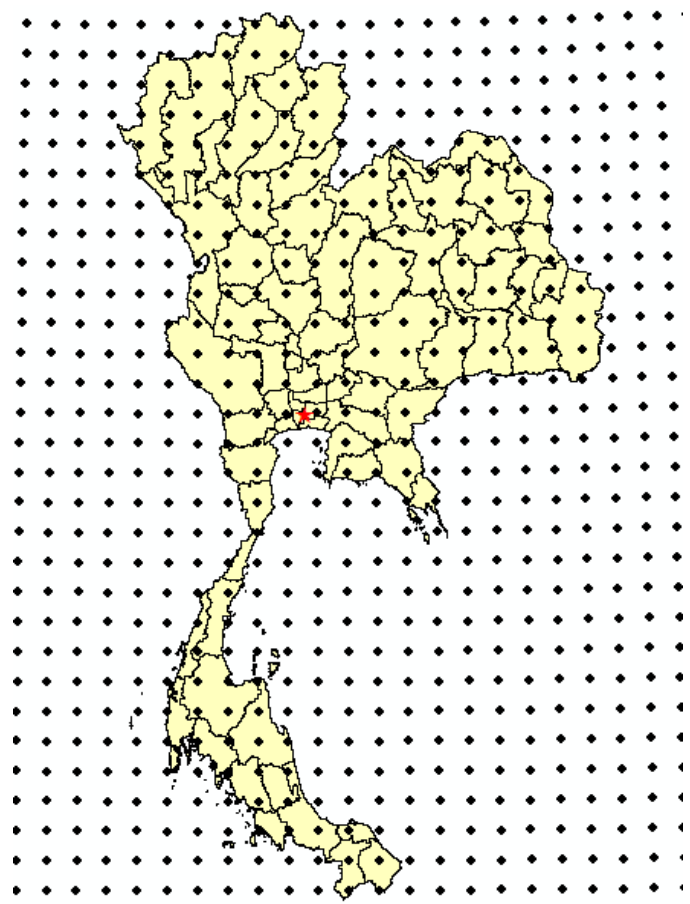

Figure 11. Climate model grid boxes (dots) and the Bangkok station (red star).

Figure 14 shows the Box-whisker plots of the precipitation of 9 pairs of CMIP3-CMIP5 models. The interquartile model range for GCMs precipitation, which is spanned by the $25^{\text {th }}$ and $75^{\text {th }}$ quantiles indicated by the boxes, is closer to the observed data for CMIP5 than CMIP3 models (Except CSIRO-Mk3.6). The spread in precipitation is generally large for three models of CMIP3 (CSIRO-Mk3.0, GFDL-CM2.0, GFDL-CM2.1) and one model of CMIP5 (CSIRO-Mk3.6). Majority of the GCMs in both CMIP3 and CMIP5 models shows higher mean precipitation than median precipitation.

Statistical downscaling with distribution mapping (DM) [40] is used in this study. We downscale precipitation for each 9 model pairs from both generations of models (CMIP3 and CMIP5) and computed with respect to Bangkok station observed data. Then, we also evaluate models agreement on projecting mean climatology at the last two decades of twentieth century (1980-1999). Specifically we generate changes in projection precipitation 


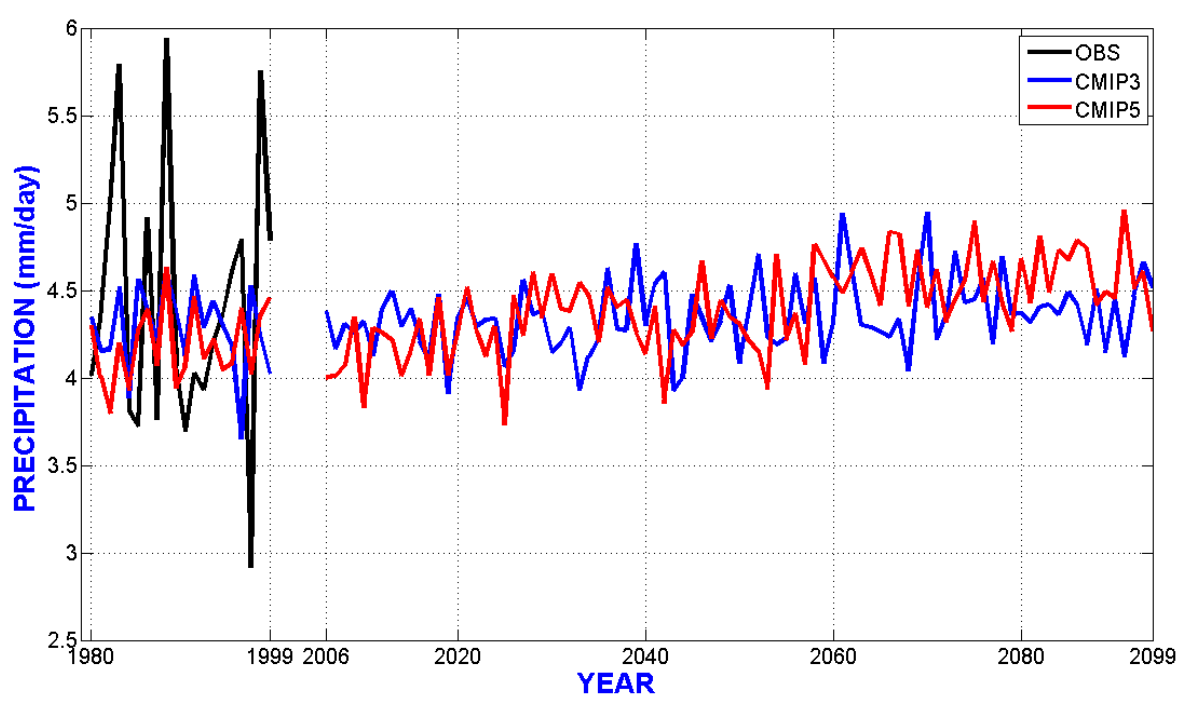

Figure 12. Time series plots and MME for annual mean precipitation climatology.

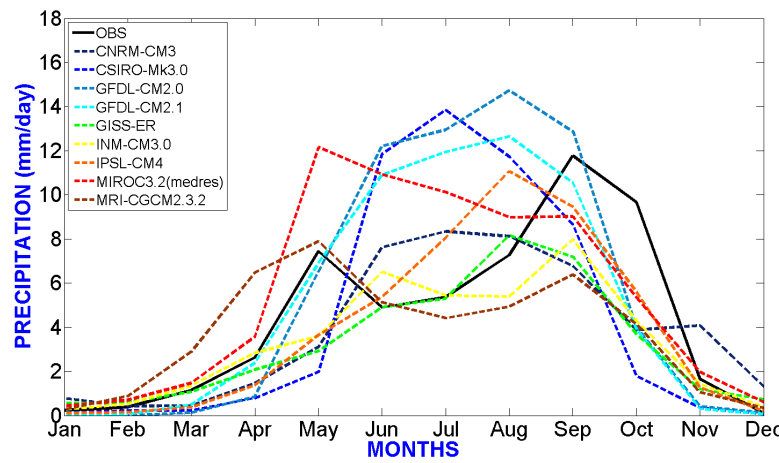

(a)

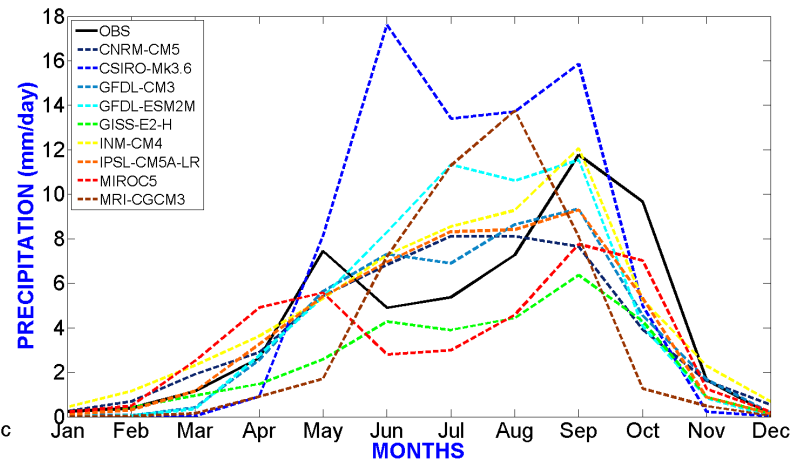

(b)

Figure 13. Mean monthly precipitation of 9 pairs of CMIP3 and CMIP5 models for the twentieth century (1980-1999). (a) CMIP3; (b) CMIP5.

for all model pairs from CMIP3 and CMIP5 with three target periods, the near future (2010-2039), the middle future (2040-2069) and the far future (2070-2099).

The similarity between observed and model-simulated field can be described by the Taylor diagram. The reference data set is plotted along the abscissa. The model data set is plotted in the first or second quadrant depending upon whether the correlation coefficient is positive or negative, respectively. The azimuthal position of model data is given by the arccosine of correlation coefficient between reference and model data set. The radial distances of reference and model data points from the origin are proportional to their standard deviations. The centered RMS error is proportional to the distance between the points representing reference and model data sets. The closer a model point is to the reference data point, the lower its centered RMS error; it implies that the model is performing relatively well. High correlation between reference and model data signifies model-simulated seasonal cycles are reasonably phased. In this study we use observations (TMD data) as a baseline for measuring historical performance while the ensemble medians are used as baseline for multi-model performance measuring in the future.

Figure 15 shows Taylor Diagrams of annual mean precipitation for CMIP3 and CMIP5 models. Figure 14(a) is for the historical period. Figures 15(b)-(d) are for the target future periods which the left figures are results of CMIP3 (B1) and CMIP5 (RCP4.5), and the right pictures are results of CMIP3 (A2) and CMIP5 (RCP8.5). It can be seen that both model generations performed reasonably well in capturing the amplitude and phasing of past mean annual precipitation over Bangkok. The correlation coefficient over Bangkok from all models lies between $0.6-0.8$, implying most of the models simulates the mean rainfall reasonably well. In addition, both 


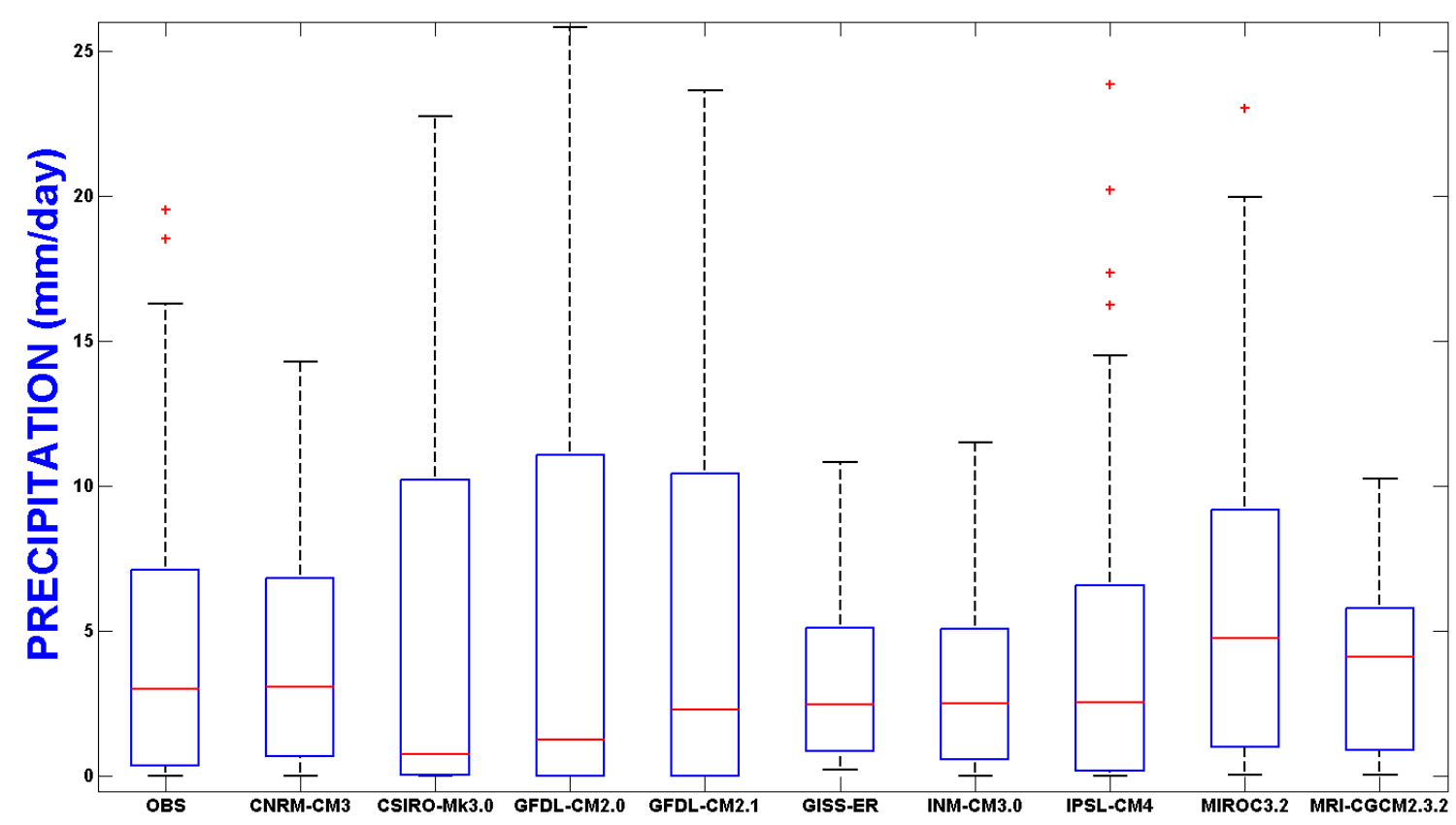

(a)

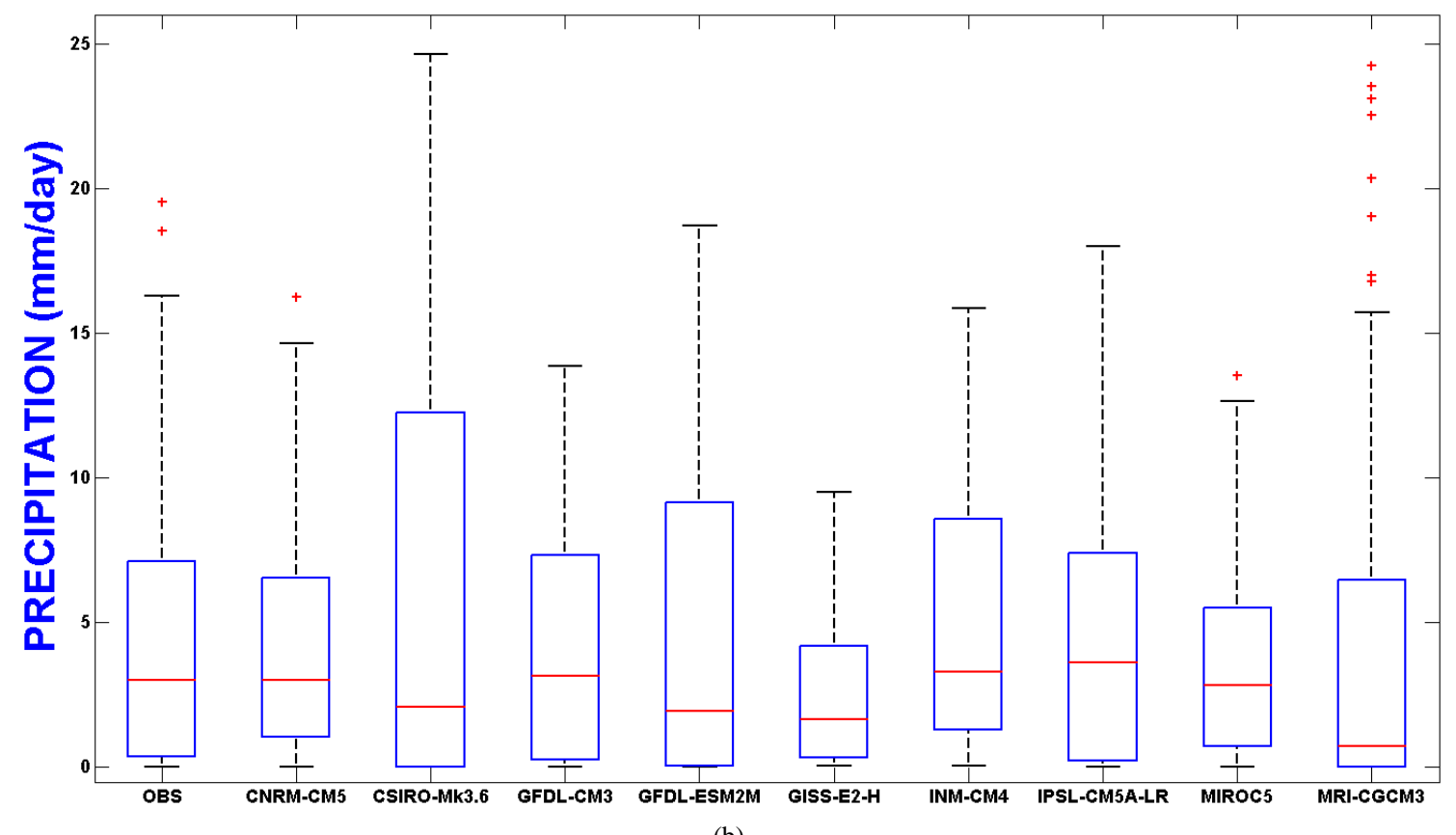

(b)

Figure 14. Box-whisker plots of precipitation of 9 pairs of CMIP3 and CMIP5 models for the twentieth century (1980-1999). (a) CMIP3; (b) CMIP5.

model generations have approximately the same standard deviation as the observed, implying similar spatial variability. However, they are different in RMS error. The correlation coefficient for the target future periods (Figures 15(b)-(d)) does not change significantly from the historical data. Both CMIP3 and CMIP5 models still simulate the timing of rainfall reasonably well. However, more spatial variability and more RMS error are found for all future periods compared to the historical period. In addition, the results of CMIP3 (A2) and CMIP5 (RCP8.5) show higher spatial variability and higher RMS error than results of CMIP (B1) and CMIP5 (RCP4.5), especially for the far future period. Therefore, the past model performance does not guarantee future results. 


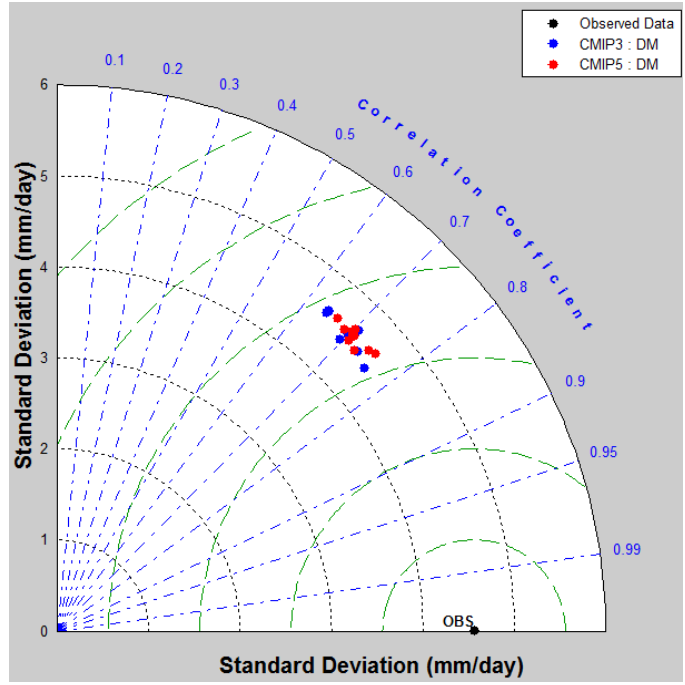

(a)
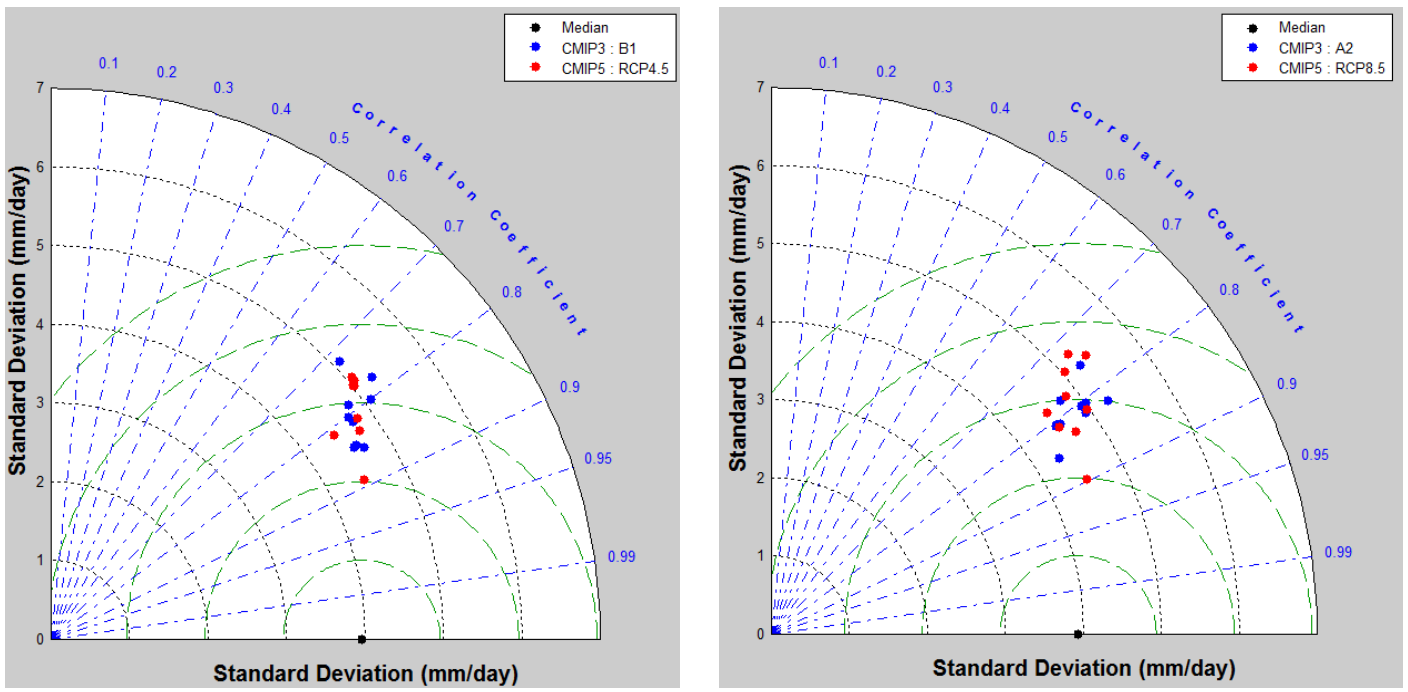

(b)
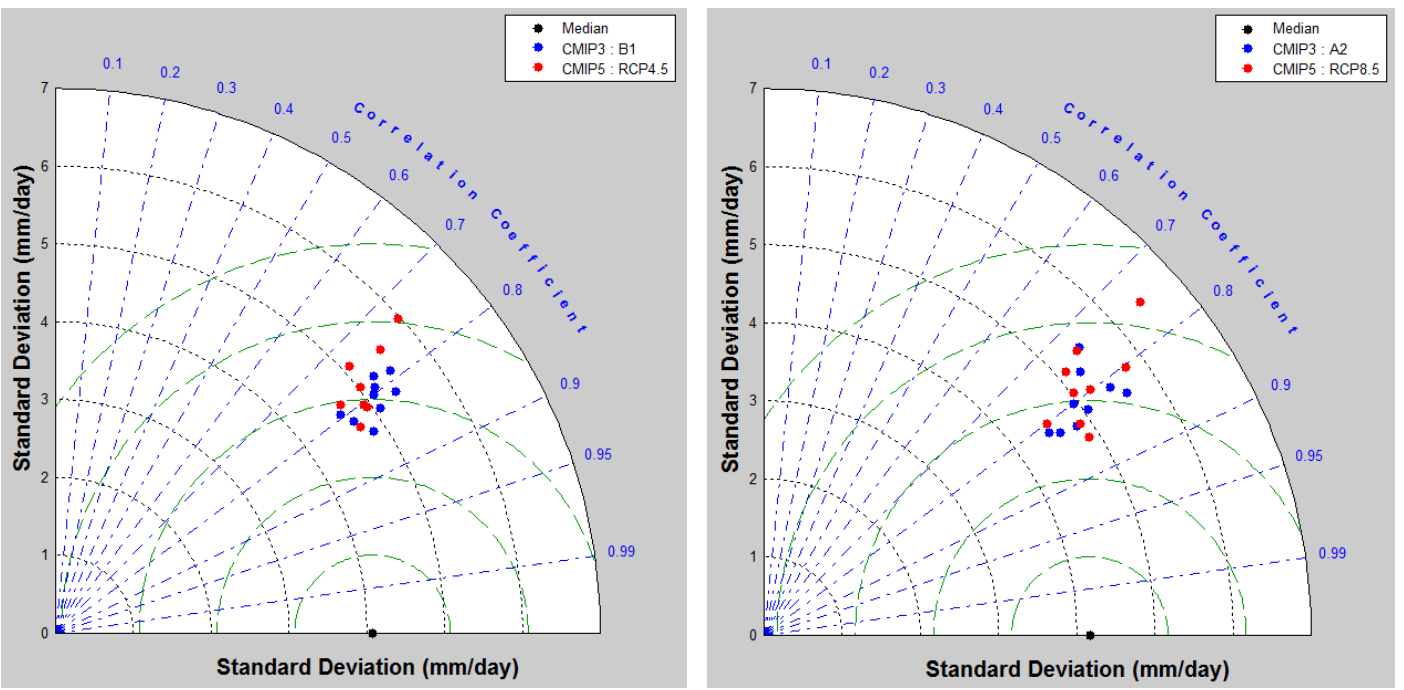

(c) 

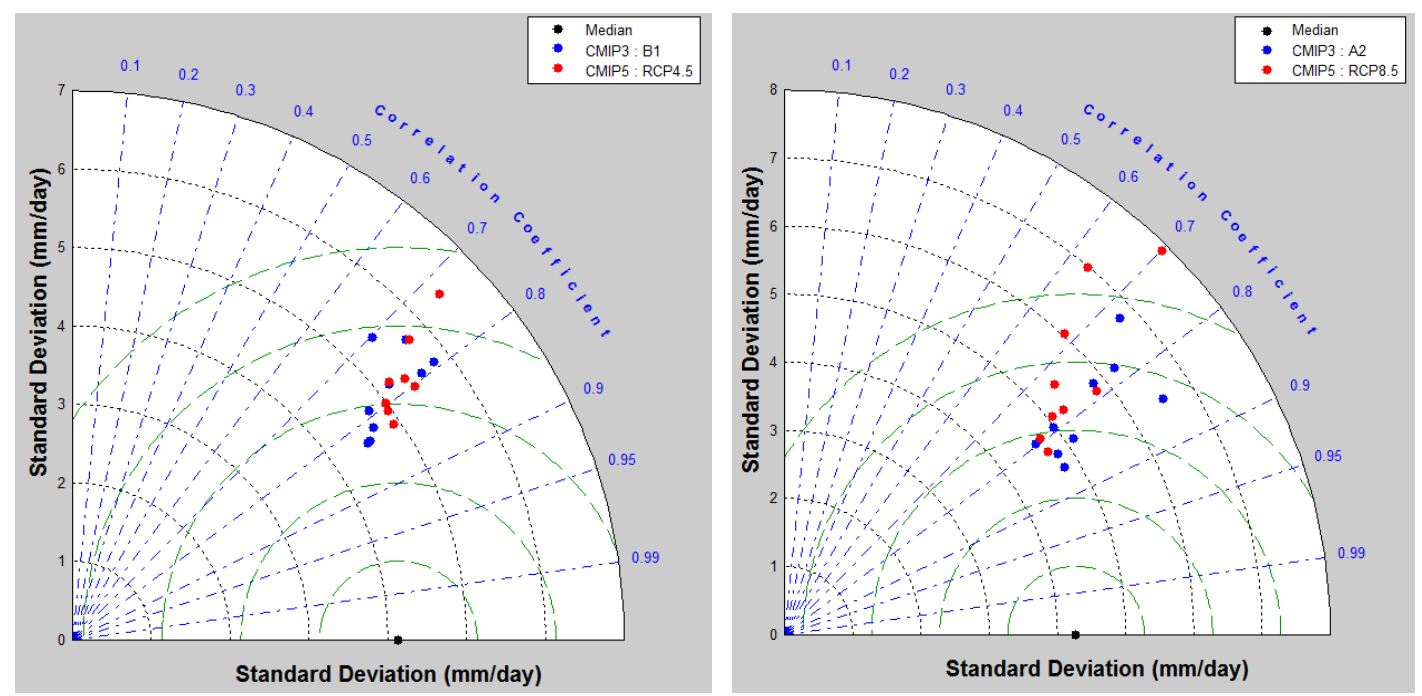

(d)

Figure 15. Taylor diagram of the annual mean precipitation climatology for left pictures: CMIP3 (B1), CMIP5 (RCP4.5) and right pictures: CMIP3 (A2), CMIP5 (RCP8.5). (a) The twentieth century (1980-1999); (b) Near future (2010-2039); (c) Mid. future (2040-2069); (d) Far future (2070-2099).

The future rainfall over Bangkok are analysed for period 2010-2099 for all scenarios in this study. The delta change factor approach is used to indicate the difference between future and reference day climate. The Boxwhisker plots of annual variation of precipitation of CMIP3 and CMIP5 models for all scenarios in this study are given in Figure 16. Both the CMIP3 and CMIP5 ensembles show double peaks of the precipitation in May and September for all future periods with higher mean and median precipitation peaks of CMIP5 models. Larger spreads of the precipitation are found in the wet season (MJJASO) than in the dry season (NDJFMA). In addition, the spread in precipitation projections is generally larger for higher emission scenarios. The delta change is compiled for wet season (MJJASO) in Figure 17. The mean precipitation during the wet season of 9 pairs of CMIP3-CMIP5 models are shown for all target future periods. Results show higher variability for higher emission scenario similar to Figure 15. We observe that all CMIP3 and CMIP5 models give significant increase in precipitation for the far future period but not so much difference between the near and mid future periods. We also cannot see any improvement of CMIP5 models over CMIP3 models.

It is very interesting to examine the model performance between the use of Multi Model Median and Multi Model Mean for future projection (see Figure 18). For CMIP3 (B1) model (Figure 18(a)), the rainfall decreases $5 \%$ and nearly $2 \%$ in the near future and the mid. Future but increases nearly $2 \%$ in the far future. For CMIP5 (RCP4.5), the rainfall decreases $1 \%$ and nearly $0 \%$ in the near future and the mid. Future but increases nearly $5 \%$ in the far future. However, the Multi Model Mean (Figure 18(b)), shows continuously increased rainfall from $2 \%$ to $7 \%$ for CMIP3 (B1) and from nearly $5 \%$ to $12 \%$ for CMIP5 (RCP4.5). Similar trends are found for CMIP3 (A2) and CMIP5 (RCP8.5) models but with different scales. The use of both methods (Multi Model Median and Multi Model Mean) in the historical period does not give significant differences. Reifen and Toumi [41] recommended the Multi Model Mean for future climate change projection while Kumar et al. [42] suggested the Multi Model Median. It is still unclear in the present study unless more GCMs are performed through the whole regions in Thailand. In addition, IPCC AR5 [43] showed mean increase of 1\% - 4\% (in JJA) for RCP4.5 in Southeast Asia, implying more flood vulnerability. The complex terrain and land-sea contrast at Bangkok may contribute to this finding. Further spatial analysis for the whole Thailand will be done in the near future.

\section{Flood Impact from a Changing Climate}

One plausible consequence of global warming is acceleration of the hydrological cycle, which is simply the balance among global evapotranspiration, rainfall, surface runoff, and storage [44]. Acceleration may increase the frequency and/or intensity of extreme events, which occur annually throughout monsoon Asia. However, the flooding of the Chao Phraya, the floodplain and the lower delta are natural processes that have occurred for 

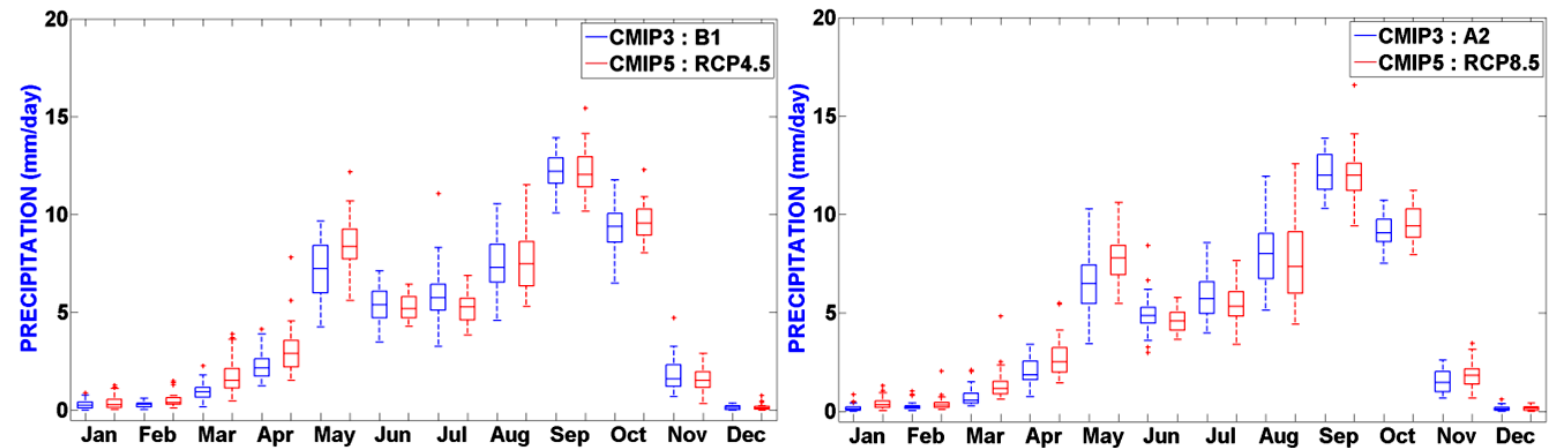

(a)
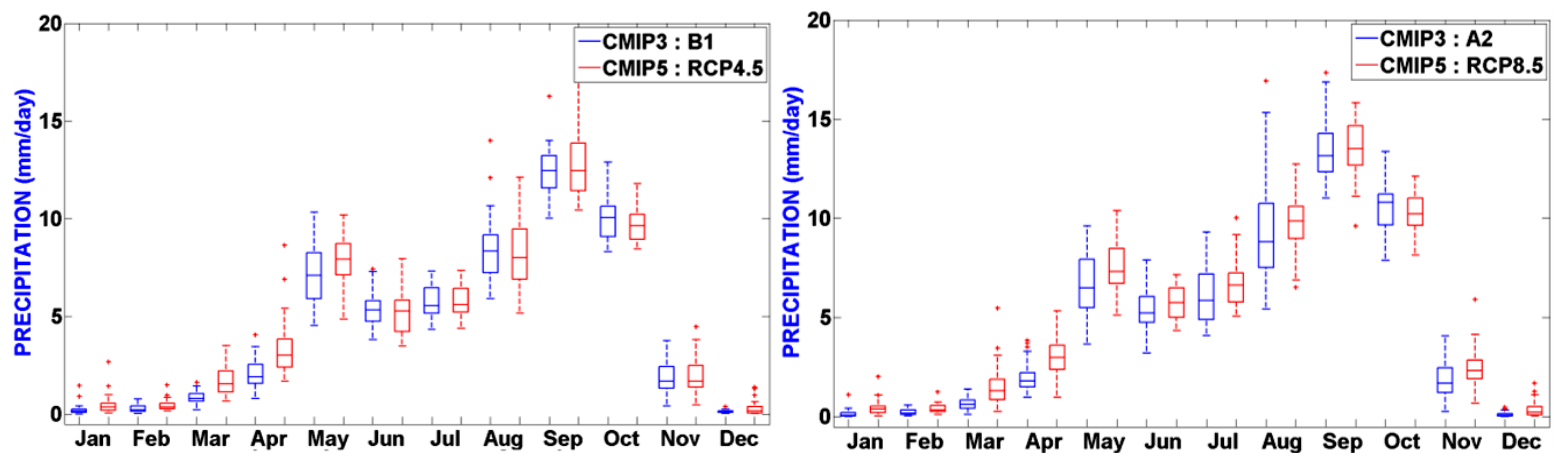

(b)
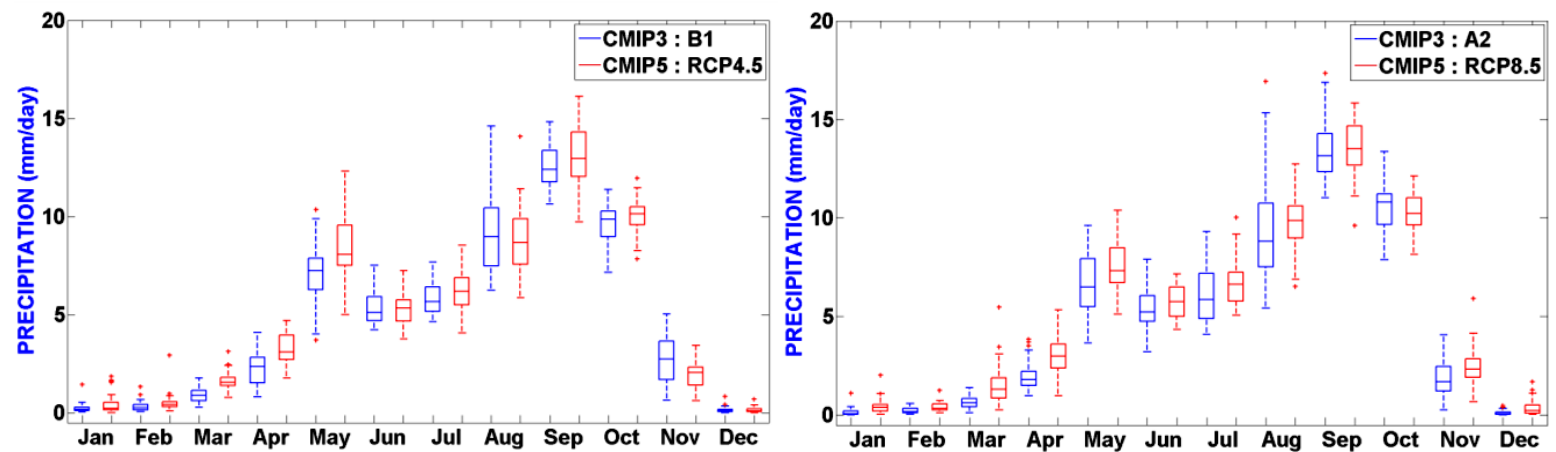

(c)

Figure 16. Box-whisker plots of precipitation of CMIP3 and CMIP5 models. (a) Near future (2010-2039); (b) Mid. future (2040-2069); (c) Far future (2070-2099).

thousands of years and will continue to occur, despite the best efforts of humans to manage the floods. Regarding the concerns on the future flooding in Bangkok and its vicinity, several studies, World Bank [45] and Kundzewicz et al. [46] indicating that Bangkok, the capital, may have to face a major flooding in the future. Significant drivers are increasing rainfall and upstream discharge, land use change, land subsidence and an increase in sea level. Of all these significant factors would result in the Bangkok and its vicinity to experience greater risk and vulnerability. De Graaf et al. [47] proposed alternative water management options to reduce vulnerability for climate change in the Netherlands. This is one of the best practices for Bangkok due to its similar urbanization, land subsidence, and sea level rise constraints.

This study covers the flood areas of the BMA (Bangkok Metropolitan Administration) and surrounding provinces (Samut Sakhon, Samut Prakan, Nakhon Pathom, and Nonthaburi). These areas are located in Chao PhrayaTha Chin river basin (about 31,885 $\mathrm{km}^{2}$ ). The downstream boundary of the computational domain was setup along the coastline from Tha Chin river to the Bangpakong river (80 km long) and $50 \mathrm{~km}$ offshore. The MIKE model family (Mike11, Mike21) similar to World Bank [48] were used in this study. The model was setup using 

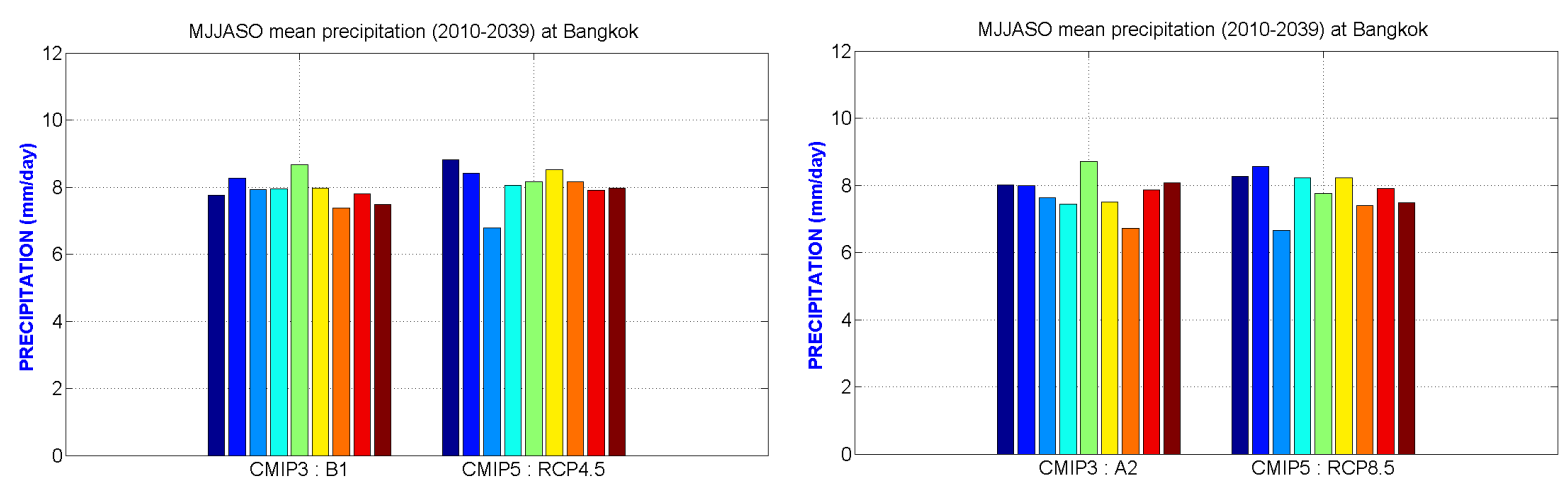

(a)
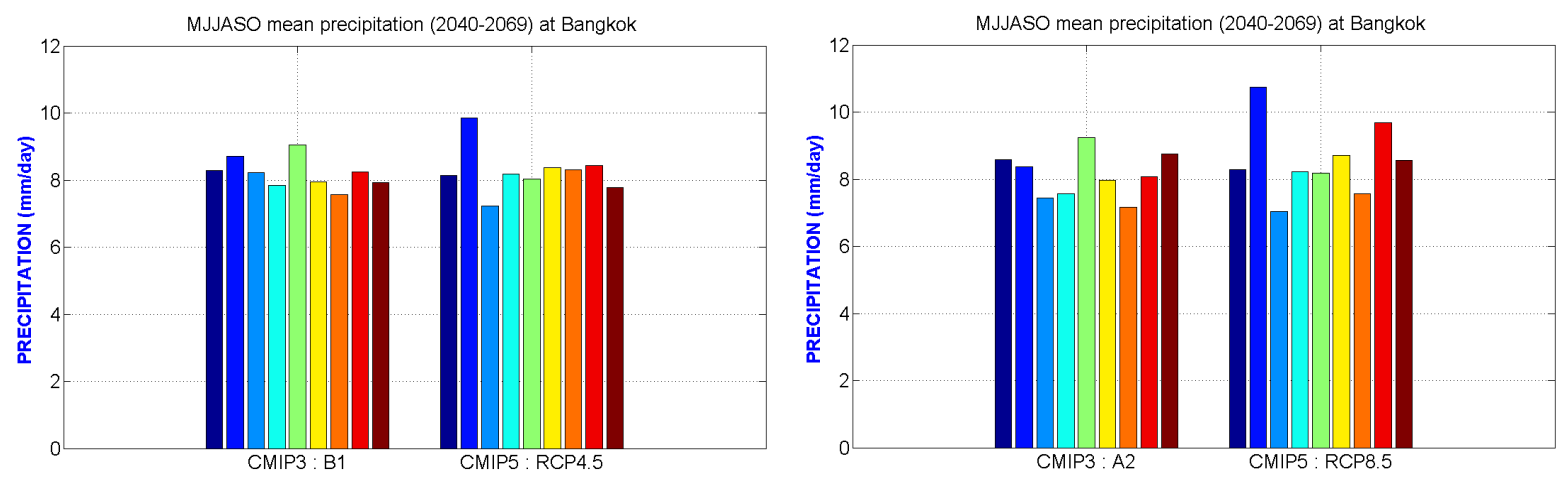

(b)
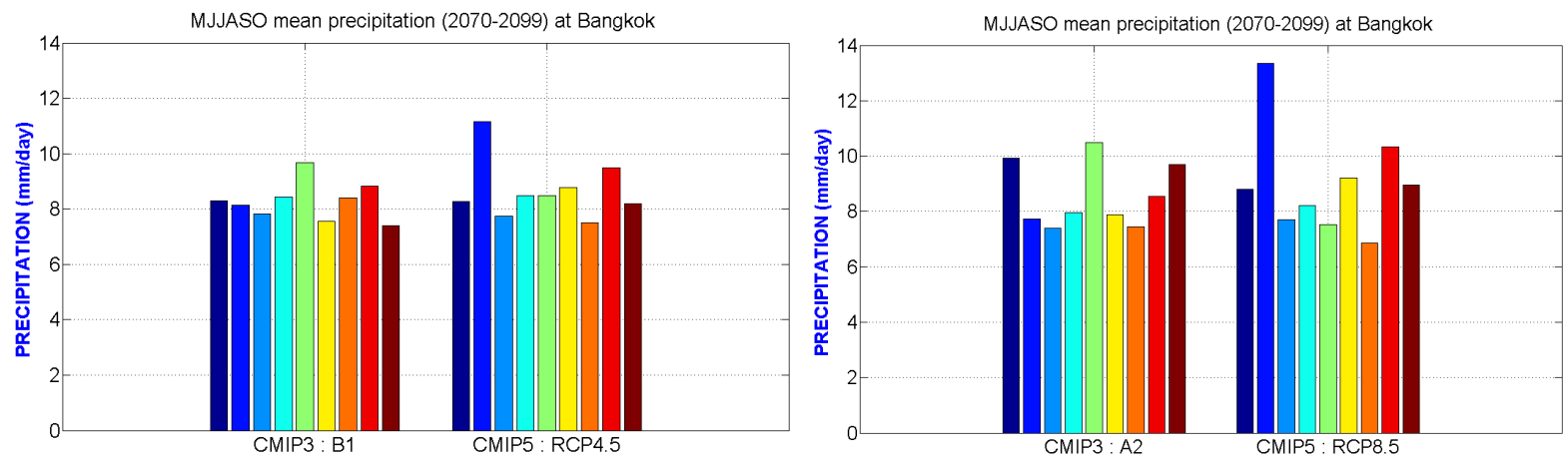

(c)

Figure 17. Mean precipitation in the wet season (MJJASO). (a) Near future (2010-2039); (b) Mid. future (2040-2069); (c) Far future (2070-2099).
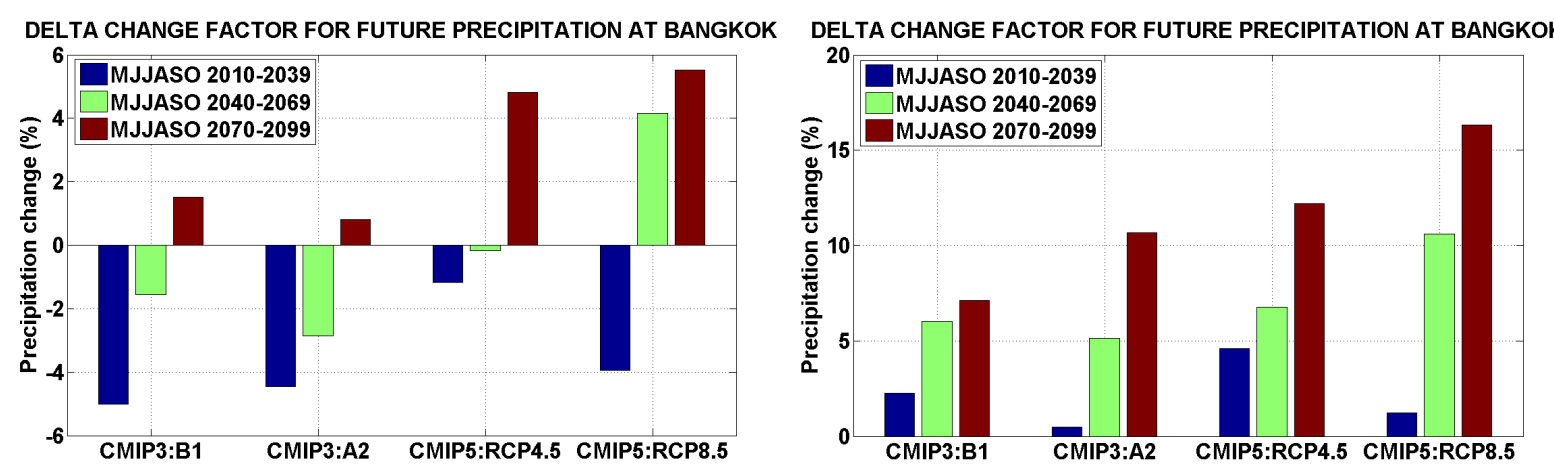

Figure 18. Delta change factor of both model generations for future mean precipitation at Bangkok. 
the 1-D Hydrodynamic model (Mike11) of the river network in the Chao Phraya-Tha Chin basin. These are simulated by 2 dimensional flow using Mike21. The computational grid size is $200 \times 200 \mathrm{~m}$ (see Figure 19). The above two models were integrated to be a single model by using the MIKE FLOOD module.

The ground surface elevation in the study area was derived from the benchmarks surveyed by the Department of Mineral Resources and the Royal Thai Survey Department. The ground survey elevation outside the study area is derived from the topographic map of 1:50,000 scale. The bathymetry was derived from an eco-sounding survey by the Hydrographic Department. The channel cross-section was surveyed by Royal Irrigation Department (RID) from the upstream (Nakhon Sawan province) to the downstream at the river mouth by the distance of $375 \mathrm{~km}$. The Tha Chin river cross-section was input from the Wat Sing District, Chainat Province to the downstream station at the Tha Chin river mouth by the distance of $319 \mathrm{~km}$. Several tributary channels in the Chao Phraya-Tha Chin basin were also included in the river network.

The discharge data of the Chao Phraya river (at the Chao Phraya dam) and the discharge release from the Rama IV Dam of the Pa Sak river were used as the upstream boundary conditions. The tidal level was input as the downstream boundary for the coastal area. The measured rainfall was also input at each gauging station for rainfall-runoff computation in the sub-catchment. The model was calibrated and verified by the flood event of the year 2002 and 1995, respectively.

Warming of the global climate system will have a multitude of impacts on the monsoon-driven climate of Bangkok. Based on analysis from Section 5, by 2050, the basin mean precipitation will rise by (2\%, 3\%) corresponding to CMIP3 (B1, A1FI). Figure 20 shows only the maximum water level for the future flood scenario A1FI 2050 case [49] compared to the present-day flood of 30 year return period. It is found that the total inundation area will increase from $550.37 \mathrm{~km}^{2}$ in present day to $733.92 \mathrm{~km}^{2}$ in 2050 or $33.35 \%$ for A1FI. Many areas may have to be inundated for 1 - 2 months (Blue shade area), beginning from the upstream provinces, Ayutthaya, the whole area of Pathum Thani Province, most area of Nonthaburi Province and some areas of Thonburi and

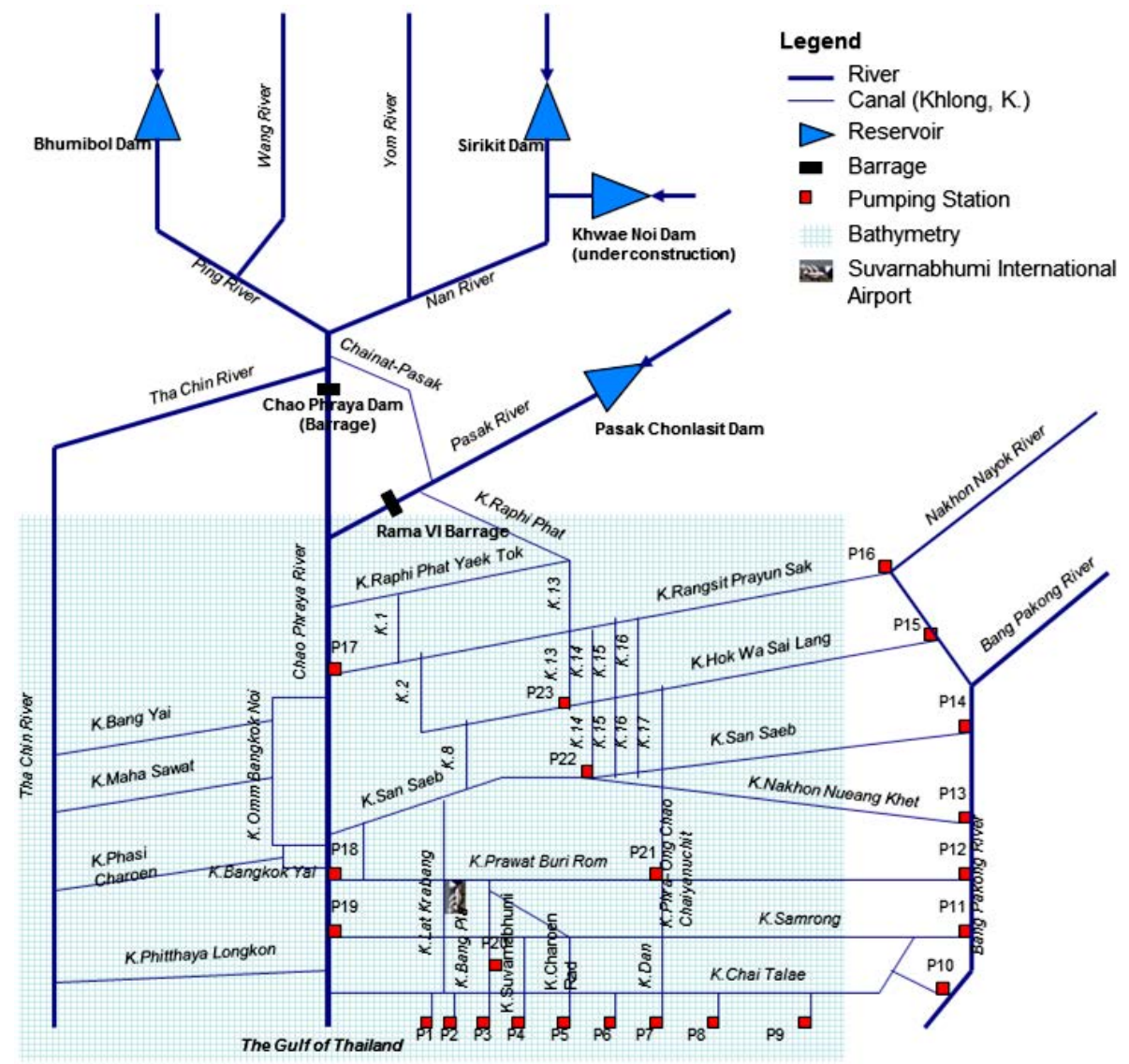

Figure 19. Model configuration (World Bank [48]). 


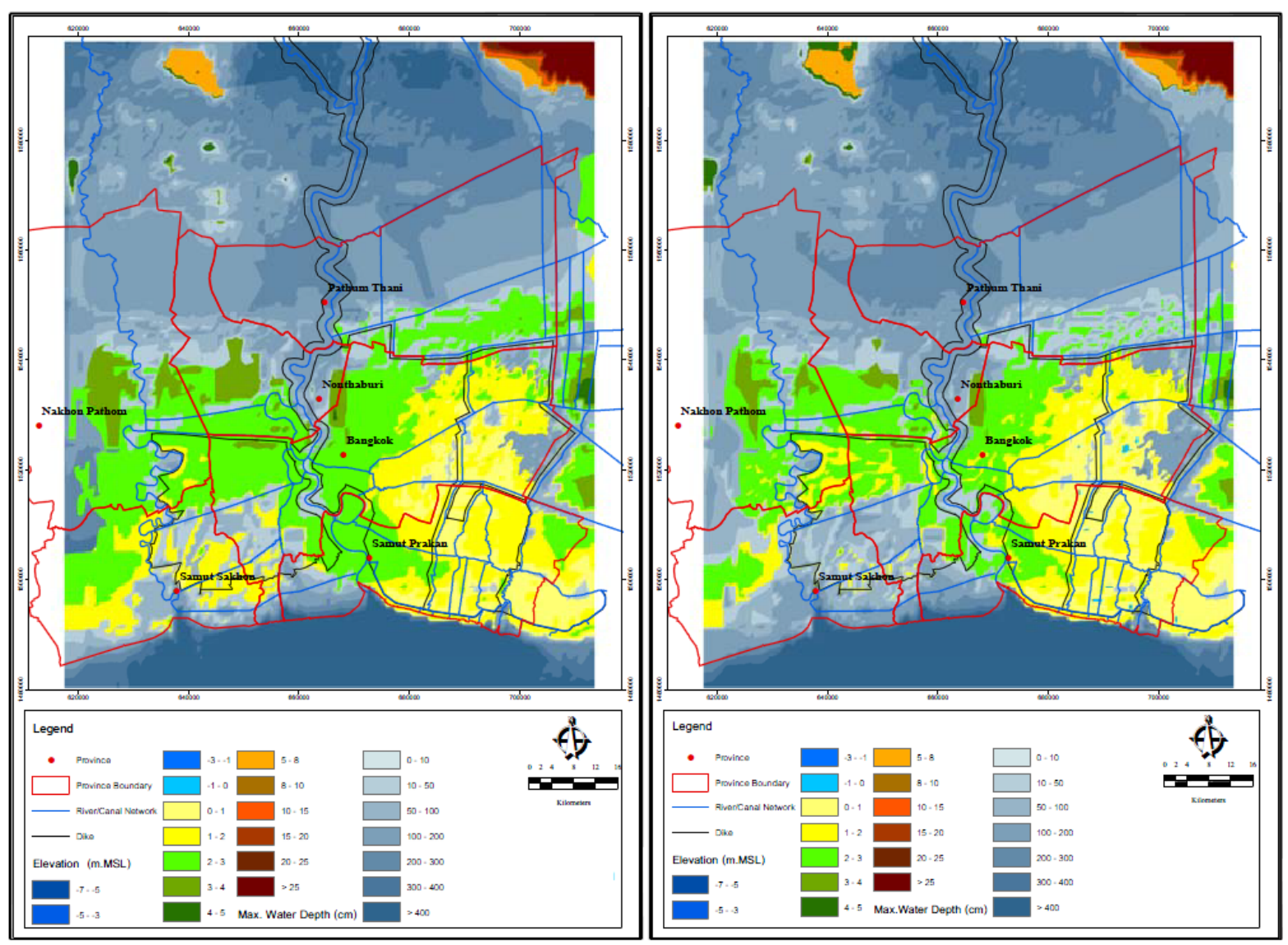

Figure 20. Flood map in a changing climate (CMIP3-A1FI, World Bank [48]).

eastern Bangkok. With the flood protection system (polder dike and pumping system), most of the areas east of Bangkok will be protected except some areas where the crest elevations of dikes are not high enough. For the western area of Bangkok, the crest elevations of dikes are not high enough to protect against flood and sea level rise, especially in the west and south of the area.

The inundation area on both banks of the Chao Phraya river will expand where the crest elevations of dikes are not high enough. However, the water level will be higher than the crest elevations of dikes along the river banks, but the duration is during the high tide period, so the flood water will not flow into the inner area of Bangkok. Furthermore, the inside drainage system can drain the overflow water into the rivers and the Gulf of Thailand, resulting in less inundation area in the east and the city core of Bangkok. The initial cost of damages was estimated at about THB 150,000 million. More importantly, there will be a major difficulty in administration and management of given measures which will not be able to use suitably and efficiently owing that the future floods will be too complicated and too severe.

Immediately after the 2011 great flood, several adaptation measures were proposed (see Figure 21). Both hard and soft-engineering approaches are used as suggested in the work of Refsgaard et al. [50] who introduced the uncertainty framework for climate change impacts and adaptation options in four water related sectors in Denmark. In this study we examine 4 case studies by using similar Mike11 model. The 1 st case study is the base case of the 2011 flood (Do nothing). The inundation area (for the lower Chao Phaya river) is found approximately 8.8 million Rais $\left(14,080 \mathrm{~km}^{2}\right)$. The use of 2 million Rais $\left(3200 \mathrm{~km}^{2}\right)$ as retention basin in the $2^{\text {nd }}$ case study can reduce the inundation area by $18 \%$ or 7.2 million Rais $\left(11,520 \mathrm{~km}^{2}\right)$. The $3^{\text {rd }}$ case study is the use of east floodway of $1000 \mathrm{~cm}$ capacity. This can reduce reduce the inundation area by $35 \%$ or 5.7 million Rais $\left(9120 \mathrm{~km}^{2}\right)$. The $4^{\text {th }}$ case study is the use of both floodways (East and west of $1000 \mathrm{~cm}$ per each). This can reduce the inundation area by $42 \%$ from the 2011 flood event. Therefore, flood cannot be completely avoided in the central part. The Integrated Flood Management in the Chao phraya basin considering flood-resilient ap- 
proach has to be adopted for sustainable future. One of the best practices is to raise the house with open space in the first floor as shown in Figure 22.

\section{Conclusions}

Reliable estimates of precipitation are essential for both research and practical applications. CMIP3 and CMIP5 climate simulations provide both historical simulations and future projections of climate extreme. The 2011 monsoon season was one of case studies with exceptionally heavy and led to extensive and long-lasting flooding in the Chao Phraya river basin, Thailand. Flooding was exacerbated by the rapid expansion of urban areas into flood plains and was the costliest natural disaster in the country's history, with direct damages estimated at US\$45 billion. In this study, we examine the flood behavior and did lesson learnt, then we look in the future flood risk and flood vulnerability by performing precipitation downscaling and simulating of the flood inundation by hydrodynamic model (Mike11 and Mike21). The comparison across two generations of the global climate model ensembles CMIP3 and CMIP5, were made through historical twentieth century and future projections. Pairwise were performed for 9 climate models ranging from time series plots and Taylor diagrams. It is

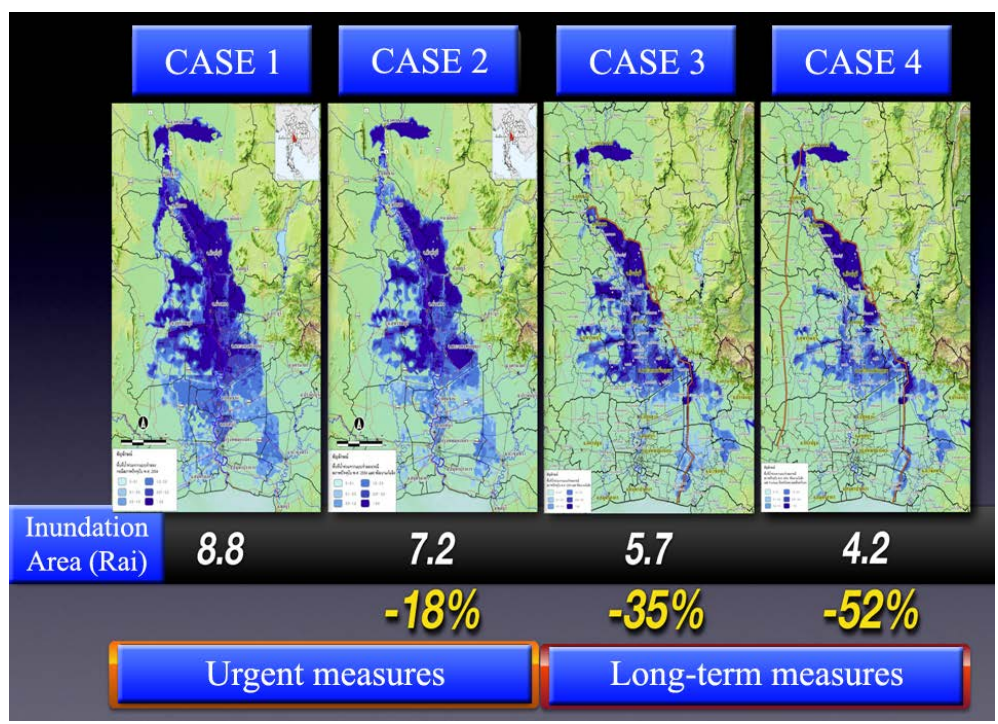

Figure 21. Adaptation measures.

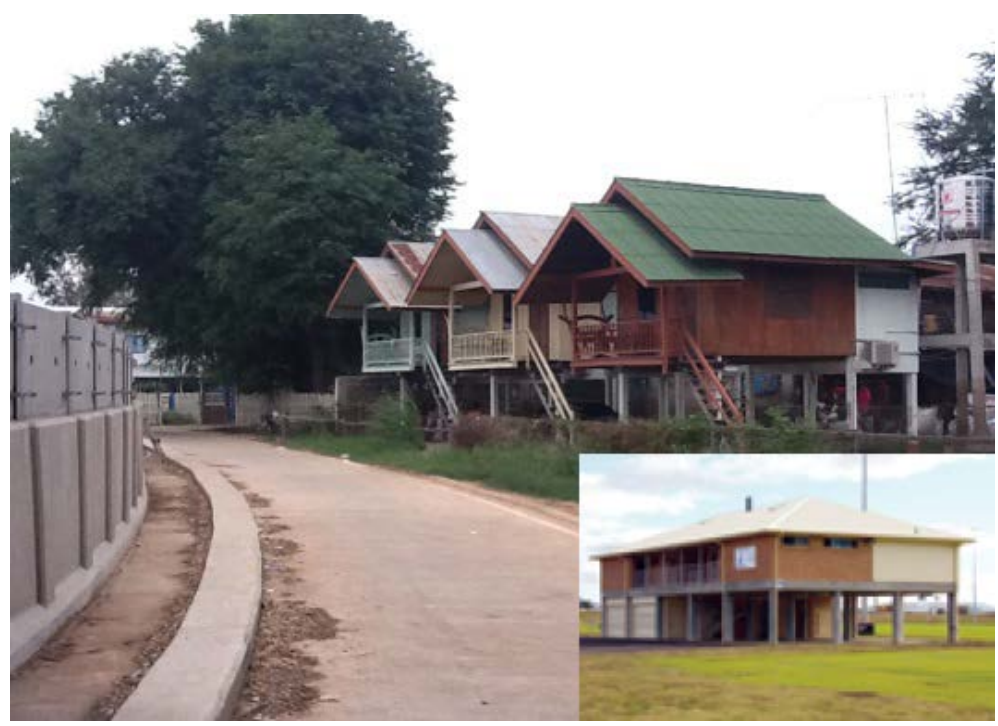

Figure 22. Raised floor house with open space. 
found that the majority of CMIP5 models shows double peaks of precipitation (in May and September) similar to the observed data. However, both models overestimate the dry spell and underestimate the peak precipitation. The interquartile model range for GCMs precipitation, which is spanned by the $25^{\text {th }}$ and $75^{\text {th }}$ quantiles, is closer to the observed data for CMIP5 than CMIP3 models. However, overall results suggest that the performance of CMIP5 models cannot be readily distinguished from of CMIP3 models, although there are clear signals of improvements over Bangkok. Both model generations perform reasonably well in capturing the amplitude and phasing of past mean annual precipitation over Bangkok. The correlation coefficient over Bangkok from all models lies between $0.6-0.8$, implying most of the models simulates the mean rainfall reasonably well. In addition, both model generations have approximately the same standard deviation as the observed, but more spatial variability and more RMS error are found for future projections. Therefore, the past model performance does not guaranteed future results. The precipitation change projection, in the rainy season, were examined through Multi Model mean and Multi Model median of 9 GCMs. Use of the Multi Model mean show continuously increased rainfall from the near future to the far future. The Multi Model Median shows increased rainfall only for the far future. It is still unclear unless more GCMs are performed through the whole regions in Thailand.

Then, we apply a flood simulation model to examine the 2011 flood behavior including adaptation measures for a changing climate. It was found that several areas in the lower Chao Phraya river basin have to be inundated for 1 - 2 months. The initial cost of damages was estimated at about THB 150,000 million. Four adaptation measures are investigated. The 1st case study is the base case of the 2011 flood (Do nothing). The inundation area was found approximately $14,080 \mathrm{~km}^{2}$. The use of $3200 \mathrm{~km}^{2}$ as retention basin in the $2^{\text {nd }}$ case study can reduce the inundation area by $18 \%$ or $11,520 \mathrm{~km}^{2}$. The $3^{\text {rd }}$ case study is the use of east floodway of $1000 \mathrm{~cm}$ capacity. This can reduce the inundation area by $35 \%$ or $9120 \mathrm{~km}^{2}$. The $4^{\text {th }}$ case study is the use of both floodways (East and west of $1000 \mathrm{~cm}$ per each). This can reduce the inundation area by $42 \%$ from the 2011 flood event. Bangkok is still under threat of flooding. In summary, the flood in the Chao Phraya river basin cannot be completely avoided. Therefore, the best practice for high flood risk communities by raising the house with open space in the first floor should be used as one of the flood resilient approach.

\section{Acknowledgements}

The author is grateful for the valuable comments of anonymous reviewers, who contributed to an improvement of this paper. Thanks also to the Thai Meteorological Department and the Royal Irrigation Department for providing the observed rainfall and discharge data. The climate model datasets were obtained from PCMDI archive.

\section{References}

[1] IPCC (2007) Climate Change 2007: The Physical Science Basis. Contribution of Working Group I to the Fourth Assessment Report of the Intergovernmental Panel on Climate Change. Solomon, S., Qin, D., Manning, M., Chen, Z., Marquis, M., Averyt, K.B., Tignor, M. and Milller, H.L., Eds., Cambridge University Press, Cambridge, and New York, 996 p.

[2] McGranahan, G., Balk, D. and Anderson, B. (2007) The Rising Tide: Assessing the Risks of Climate Change and Human Settlements in Low Elevation Coastal Zones. Environment and Urbanization, 19, 17-37. http://dx.doi.org/10.1177/0956247807076960

[3] Nicholls, R.J., Hanson, S., Herweijer, C., Patmore, N., Hallegatte, S., Corfee-Morlot, J., Chateau, J. and Muir-Wood, R. (2008) Ranking Port Cities with High Exposure and Vulnerability to Climate Extremes-Exposure Estimates. Environmental Working Paper No. 1, Organisation for Economic Co-operation and Development (OECD), Paris.

[4] Sivakumar, B. (2011) Global Climate Change and Its Impacts on Water Resources Planning and Management: Assessment and Challenges. Stochastic Environmental Research and Risk Assessment, 25, 583-600. http://dx.doi.org/10.1007/s00477-010-0423-y

[5] Cayan, D.R., Maurer, E.P., Dettinger, M.D., Tyree, M. and Hayhoe, K. (2008) Climate Change Scenarios for the California Region. Climatic Change, 87, 21-42. http://dx.doi.org/10.1007/s10584-007-9377-6

[6] Wehner, M. (2013) Methods of Projecting Future Changes in Extremes. In: Extremes in a Changing Climate, Springer, Netherlands, 223-237. http://dx.doi.org/10.1007/978-94-007-4479-0 8

[7] IPCC (2007) Climate Change 2007: Impacts, Adaptation, and Vulnerability. Exit EPA Disclaimer Contribution of Working Group II to the Third Assessment Report of the Intergovernmental Panel on Climate Change. Parry, M.L., et al., Eds., Cambridge University Press, Cambridge.

[8] Schubert, S.D. and Lim, Y.K. (2013) Climate Variability and Weather Extremes: Model-Simulated and Historical Data. 
In: Extremes in a Changing Climate, Springer, Netherlands, 239-285.

http://dx.doi.org/10.1007/978-94-007-4479-0_9

[9] Delworth, T.L., Broccoli, A.J., Rosati, A., Stouffer, R.J., Balaji, V., Beesley, J.A., et al. (2006) GFDL’s CM2 Global Coupled Climate Models. Part 1: Formulation and Simulation Characteristics. Journal of Climate, 19, 643-674. http://dx.doi.org/10.1175/JCLI3629.1

[10] Perkins, S.E., Pitman, A.J., Holbrook, N.J. and Mcaneney, J. (2007) Evaluation of the AR4 Climate Models' Simulated Daily Maximum Temperature, Minimum Temperature, and Precipitation over Australia Using Probability Density Functions. Journal of Climate, 20, 4356-4376. http://dx.doi.org/10.1175/JCLI4253.1

[11] Johnson, F. and Sharma, A. (2009) Measurement of GCM Skill in Predicting Variables Relevant for Hydroclimatological Assessments. Journal of Climate, 22, 4373-4382. http://dx.doi.org/10.1175/2009JCLI2681.1

[12] Van Vuuren, D.P., Edmonds, J., Kainuma, M., Riahi, K., Thomson, A., Hibbard, K., Hurtt, G.C., Kram, T., Krey, V., Lamarque, J.F., Masui, T., Meinshausen, M., Nakicenovic, N., Smith, S.J. and Rose, S.K. (2011) The Representative Concentration Pathways: An Overview. Climatic Change, 109, 5-31. http://dx.doi.org/10.1007/s10584-011-0148-z

[13] Meinshausen, M., Smith, S.J., Calvin, K., Daniel, J.S., Kainuma, M.L.T., Lamarque, J.F., et al. (2011) The RCP Greenhouse Gas Concentrations and Their Extensions from 1765 to 2300. Climatic Change, 109, 213-241. http://dx.doi.org/10.1007/s10584-011-0156-z

[14] Chaturvedi, R.K., Joshi, J., Jayaraman, M., Bala, G. and Ravindranath, N.H. (2012) Multi-Model Climate Change Projections for India under Representative Concentration Pathways. Current Science, 103, 791-802.

[15] Taylor, K.E., Stouffer, R.J. and Meehl, G.A. (2012) An Overview of CMIP5 and the Experimental Design. Bulletin of the American Meteorological Society, 93, 485-498. http://dx.doi.org/10.1175/BAMS-D-11-00094.1

[16] Taylor, K.E., Stouffer, R.J. and Meehl, G.A. (2011) A Summary of the CMIP5 Experiment Design. Program for Climate Model Diagnosis and Intercomparison (PCMDI), 2011. http://cmip-pcmdi.llnl.gov/cmip5/docs/Taylor_CMIP5_design.pdf

[17] Taylor, K.E., Balaji, V., Hankin, S., Juckes, M., Lawrence, B. and Pascoe, S. (2011) CMIP5 Data Reference Syntax (DRS) and Controlled Vocabularies (Program for Climate Model Diagnosis and Intercomparison (PCMDI). http://cmip-pcmdi.llnl.gov/cmip5/docs/cmip5_data_reference_syntax.pdf

[18] Meehl, G.A., Goddard, L., Murphy, J., Stouffer, R.J., Boer, G., Danabasoglu, G., et al. (2009) Decadal Prediction: Can It Be Skillful? Bulletin of the American Meteorological Society, 90, 1467-1485. http://dx.doi.org/10.1175/2009BAMS2778.1

[19] Kug, J.S., Ham, Y.G., Lee, J.Y. and Jin, F.F. (2012) Improved Simulation of Two Types of El Niño inCMIP5 Models. Environmental Research Letters, 7, Article ID: 034002. http://dx.doi.org/10.1088/1748-9326/7/3/034002

[20] Brands, S., Herrera, S., Fernández, J. and Gutiérrez, J.M. (2013) How Well Do CMIP5 Earth System Models Simulate Present Climate Conditions in Europe and Africa? Climate Dynamics, 41, 803-817. http://dx.doi.org/10.1007/s00382-013-1742-8

[21] Blázquez, J. and Nuñez, M.N. (2013) Analysis of Uncertainties in Future Climate Projections for South America: Comparison of WCRP-CMIP3 and WCRP-CMIP5 Models. Climate Dynamics, 41, 1039-1056. http://dx.doi.org/10.1007/s00382-012-1489-7

[22] Cattiaux, J., Douville, H. and Peings, Y. (2013) European Temperatures in CMIP5: Origins of Present-Day Biases and Future Uncertainties. Climate Dynamics, 41, 2889-2907. http://dx.doi.org/10.1007/s00382-013-1731-y

[23] Knutti, R., Abramowitz, G., Collins, M., Eyring, V., Gleckler, P.J., Hewitson, B.M. and Mearns, L. (2010) Good Practice Guidance Paper on Assessing and Combining Multi Model Climate Projections. Meeting Report of the Intergovernmental Panel on Climate Change Expert Meeting on Assessing and Combining Multi Model Climate Projections. IPCC Working Group I Technical Support Unit, University of Bern, Bern.

[24] Mehrotra, R., Sharma, A., Bari, M., Tuteja, N. and Amirthanathan, G. (2014) An Assessment of CMIP5 Multi-Model Decadal Hindcasts over Australia from a Hydrological Viewpoint. Journal of Hydrology, 519, 2932-2951. http://dx.doi.org/10.1016/j.jhydrol.2014.07.053

[25] Graham, L.P., Andreasson, J. and Carlsson, B. (2007) Assessing Climate Change Impacts on Hydrology from an Ensemble of Regional Climate Models, Model Scales and Linking Methods-A Case Study on the Lule River Basin. Climatic Change, 81, 293-307. http://dx.doi.org/10.1007/s10584-006-9215-2

[26] Leander, R., Adri Buishand, T., van den Hurk, B.J.J.M. and de Wit, M.J.M. (2008) Estimated Changes in Flood Quantiles of the River Meuse from Resampling of Regional Climate Model Output. Journal of Hydrology, 351, 331-343. http://dx.doi.org/10.1016/j.jhydrol.2007.12.020

[27] Wilby, R.L., Beven, K.J. and Reynard, N.S. (2008) Climate Change and Fluvial Flood Risk in the UK: More of the Same? Hydrological Processes, 22, 2511-2523. http://dx.doi.org/10.1002/hyp.6847 
[28] Willems, P., Arnbjerg-Nielsen, K., Olsson, J. and Nguyen, V.T.V. (2011) Climate Change Impact Assessment on Urban Rainfall Extremes and Urban Drainage: Methods and Shortcomings. Atmospheric Research, 103, 106-118. http://dx.doi.org/10.1016/j.atmosres.2011.04.003

[29] Fiseha, B.M., Setegn, S.G., Melesse, A.M., Volpi, E. and Fiori, A. (2014) Impact of Climate Change on the Hydrology of Upper Tiber River Basin Using Bias Corrected Regional Climate Model. Water Resources Management, 28, 13271343. http://dx.doi.org/10.1007/s11269-014-0546-x

[30] World Bank (2011) The World Bank Supports Thailand’s Post-Floods Recovery Effort. The World Bank, Washington DC. http://www.worldbank.org/en/news/2011/12/13/world-bank-supports-thailands-post-floods-recovery-effort

[31] Vongvisessomjai, S. (2007) Impacts of Typhoon Vae and Linda on Wind Waves in the Upper Gulf of Thailand and East Coast. Songklanakarin Journal of Science and Technology, 29, 1199-1216.

[32] Ziegler, A.D., Lim, H.S., Jachowski, N.R. and Wasson, R.J. (2012) Water Management: Reduce Urban Flood Vulnerability. Nature, 481, 145. http://dx.doi.org/10.1038/481145b

[33] Stephens, E. and Cloke, H. (2014) Improving Flood Forecasts for Better Flood Preparedness in the UK (and Beyond). Geographical Journal, 180, 310-316. http://dx.doi.org/10.1111/geoj.12103

[34] Tarolli, P. (2013) Book Review: Natural Hazards in the Asia-Pacific Region: Recent Advances and Emerging Concepts. Natural Hazards and Earth System Sciences, 13, 2551-2552. http://dx.doi.org/10.5194/nhess-13-2551-2013

[35] Werner, M., van Dijk, M. and Schellekens, J. (2004) Delft-FEWS: An Open Shell Flood Forecasting System. In: Liong, S.Y., Phoon, K.K. and Babovic, V., Eds., Proceedings of the 6th International Conference on Hydroinformatics, World Scientific Publishing Company, Singapore City, 1205-1212.

[36] Wehner, M., Cranston, M., Harrison, T., Whitfield, D. and Schellekens, J. (2009) Recent Developments in Operational Flood Forecasting in England, Wales and Scotland. Meteorological Applications, 16, 13-22. http://dx.doi.org/10.1002/met.124

[37] World Bank (2012) Thai Flood 2011 Rapid Assessment for Resilient Recovery and Reconstruction Planning. Washington DC, 377 p.

[38] Rogelj, J., Meinshausen, M. and Knutti, R. (2012) Global Warming under Old and New Scenarios Using IPCC Climate Sensitivity Range Estimates. Nature Climate Change, 2, 248-253. http://dx.doi.org/10.1038/nclimate1385

[39] Stocker, T.F., Qin, D., Plattner, G.-K., Tignor, M., Allen, S.K., Boschung, J., Nauels, A., Xia, Y., Bex, V., Midgley, P. M., et al. (2013) Climate Change 2013. The Physical Science Basis. Working Group I Contribution to the Fifth Assessment Report of the Intergovernmental Panel on Climate Change-Abstract for Decision-Makers.

[40] Teutschbein, C. and Seibert, J. (2012) Bias Correction of Regional Climate Model Simulations for Hydrological Climate-Change Impact Studies: Review and Evaluation of Different Methods. Journal of Hydrology, 456-457, 12-29. http://dx.doi.org/10.1016/j.jhydrol.2012.05.052

[41] Reifen, C. and Toumi, R. (2009) Climate Projections: Past Performance No Guarantee of Future Skill? Geophysical Research Letters, 36, L13704. http://dx.doi.org/10.1029/2009GL038082

[42] Kumar, D., Kodra, E. and Ganguly, A.R. (2014) Regional and Seasonal Intercomparison of CMIP3 and CMIP5 Climate Model Ensembles for Temperature and Precipitation. Climate Dynamics, 43, 2491-2518. http://dx.doi.org/10.1007/s00382-014-2070-3

[43] IPCC (2013) Climate Change 2013: The Physical Science Basis. Contribution of Working Group I to the Fifth Assessment Report of the Intergovernmental Panel on Climate Change. Stocker, T.F., Qin, D., Plattner, G.K., Tignor, M., Allen, S.K., Boschung, J., Nauels, A., Xia, Y., Bex, V. and Midgley, P.M., Eds., Cambridge University Press, Cambridge and New York, 1535 p.

[44] Ziegler, A.D., Sheffield, J., Maurer, E.P., Nijssen, B., Wood, E.F. and Lettenmaier, D.P. (2003) Detection of Intensification of Continental-Scale Hydrological Cycles: Temporal Scale of Evaluation. Journal of Climate, 16, 535-547. http://dx.doi.org/10.1175/1520-0442(2003)016<0535:DOIIGA>2.0.CO;2

[45] World Bank (2010) Climate Risks and Adaptation in Asian Coastal Megacities: A Synthesis Report. Washington DC, $120 \mathrm{p}$.

[46] Kundzewicz, Z.W., Kanae, S., Seneviratne, S.I., Handmer, J., Nicholls, N., Peduzzi, P., Mechler, R., Bouwer, L.M., Arnell, N., Mach, K., Muir-Wood, R., Brakenridge, G.R., Kron, W., Benito, G., Honda, Y., Takahashi, K. and Sherstyukov, B. (2014) Flood Risk and Climate Change: Global and Regional Perspectives. Hydrological Sciences Journal, 59, 1-28. http://dx.doi.org/10.1080/02626667.2013.857411

[47] De Graaf, R., van de Giesen, N. and Van de Ven, F. (2007) The Closed City as a Strategy to Reduce Vulnerability of Urban Areas for Climate Change. Water Science \& Technology, 56, 165-173. http://dx.doi.org/10.2166/wst.2007.548

[48] World Bank (2009) Climate Change Impact and Adaptation Study for Bangkok Metropolitan. Main Report, Washington DC, 85 p. 
[49] IPCC (2000) Emissions Scenarios, Special Report of the Intergovernmental Panel on Climate Change. Nakicenovic, N. and Swat, R., Eds., Cambridge University Press, Cambridge, 570 p.

[50] Refsgaard, J.C., Arnbjerg-Nielsen, K., Drews, M., Halsnæs, K., Jeppesen, E., Madsen, H., Markandya, A., Olesen, J.E., Porter, J.R. and Christensen, J.H. (2013) The Role of Uncertainty in Climate Change Adaptation Strategies-A Danish Water Management Example. Mitigation and Adaptation Strategies for Global Change, 18, 337-359. http://dx.doi.org/10.1007/s11027-012-9366-6 